\title{
GEOGRAFSKE ZASNOVE SONARAVNEGA RAZVOJA IN SAMOOSKRBE SLOVENIJE
}

\author{
dr. Dušan Plut \\ Oddelek za geografijo, Filozofska fakulteta Univerze v Ljubljani \\ Aškerčeva 2, SI-I000 Ljubljana \\ e-mail: dusan.plut@ff.uni-lj.si
}

Izvirni znanstveni članek

COBISS 1.01

DOI: $10.4312 /$ dela.41.1.5-40

\section{Izvleček}

Prispevek obravnava geografske vidike sonaravnega razvoja in samooskrbe Slovenije. Človeštvo je zaradi rasti svetovnega prebivalstva in gospodarstva preseglo nosilnost planeta, zato je nujna temeljita sprememba razmerja med človekom in okoljem. Slovenija razpolaga s ključnimi razvojno-varovalnimi geografskimi potenciali za prehod v sonaravni razvoj, sonaravno prenovo gospodarstva in varno stopnjo prehranske ter energetske stopnje samooskrbe.

Ključne besede: sonaravni razvoj, sonaravna gospodarska usmeritev, razvojno-varovalni potenciali, samooskrba, Slovenija

\section{GEOGRAPHICAL SCHEME OF SUSTAINABLE DEVELOPMENT AND SELF-SUPPLY IN SLOVENIA}

\begin{abstract}
To overcome the crisis, both on global and regional levels, does not mean to continue the traditional developmental practice but to implement a sustainable development concept. In Slovenia, it should be implemented in the country as a whole and in all its individual regions in order to pursue the welfare of the citizens of the present and future generations and also to balance economic, social and environmental development. Slovenia has all the essential developmental-protective geographical potentials (environmental resources) that are necessary for its transition to sustainable development, sustainable reinvigoration of economy and a safe degree of food and energy levels for its self-supply.
\end{abstract}

Key words: sustainable development, sustainable economic orientation, developmental-protective potentials, self-supply, Slovenia 


\section{UVOD}

Sodobna civilizacija je vse bolj ujeta v številne primeže, finančne, energetske, socialne in podnebno-okoljske. Rastoče svetovno gospodarstvo in svetovno prebivalstvo od začetka 80. let 20. st. presegata nosilnost planeta, prepad med revnimi in bogatimi prebivalci sveta se povečuje in dobiva socialno nevarne razsežnosti. Gospodarstvo ostaja tudi v 21. st. ujetnik entropijsko, podnebno in prostorsko uničujoče predpostavke, da se lahko na končnem planetu trajno nadaljuje količinska gospodarska rast in pospešena raba omejenih zalog neobnovljivih virov okolja. Le rast absolutne porabe surovin in energije naj bi zagotavljala napredek, trajno naraščajoče materialno bogastvo (ne glede na družbene in medgeneracijske posledice) naj bi zagotavljalo srečno, kakovostno življenje. Zgolj v zadnjem četrtletju 20. st. se je svetovno gospodarstvo količinsko podvojilo, hkrati pa se ocenjuje, da je $60 \%$ svetovnih ekosistemov degradiranih. Če bi vsi prebivalci trošili toliko surovin in energije ter obremenjevali okolje kot povprečen prebivalec ZDA, bi se okoljski pritiski na okolje povečali za štirikrat, čeprav so že leta 2010 za skoraj polovico presegali zmogljivost planeta. Sicer želeno povečanje učinkovite rabe materialov in energije ne bo zadostovalo za potrebno globalno zmanjšanje pritiskov na planetarni ekosistem in omejene naravne vire (Rifkin, 2010; Plut, 2014). V obdobju ene generacije bo potrebna korenita civilizacijska sprememba v svetovnem gospodarstvu, energetiki in celotni družbi. Ekonomist Piketty (2014) opozarja tudi na zgodovinsko nevzdržnost vse večje koncentracije kapitala v rokah peščice ljudi in nevarno povečevanje družbene neenakosti v sodobnih kapitalističnih družbah. Postavlja so torej širše vprašanje najbolj primernega družbeno-ekonomskega načina hkratnega reševanja okoljskih, gospodarskih in družbenih problemov v okviru ekosocialno temeljito reformiranega kapitalizma ali/in demokratičnega ekološkega socializma (Plut, 2014).

Tudi OECD v obdobju tesnejšega primeža okoljskih in gospodarskih problemov sodi, da so t. i. »okoljsko in socialno trajnostna gospodarska rast ter zelene investicije«, torej ozelenjeno gospodarstvo, pravi kratkoročni in tudi dolgoročni odgovor za 21. st. (Declaration on green growth, 2009). Vendar poudarjajo, da je za zeleno gospodarsko rast ključna pospešena liberalizacija svetovne trgovine. Ta pa pogosto uničuje geografskim dejavnikom, lokalnemu okolju in endogenim virom prilagojene oblike kmetovanja in proizvodnje ter prezre potrebo po ohranjanju in celo povečevanju samooskrbe. Dokumenti OECD ne upoštevajo dejstva, da obstajajo planetarne in lokalne prostorske in okoljske omejitve tudi t. i. zelene gospodarske rasti, prav tako pa ne upoštevajo nujnosti ohranjanja pokrajinske, biotske in kulturološke mozaičnosti sveta.

EU je na ekonomsko krizo poskušala odgovoriti s strategijo t. i. pametne, trajnostne in vključujoče rasti (Earnings, jobs and innovation ..., 2011). Vendar tudi vse več okoljskih ekonomistov opozarja, da okoljsko sicer dokaj ambiciozen strateški dokument Evropa 2020 ni prepoznal ključne potrebe po strukturnih spremembah samega modela neskončne gospodarske rasti (Confronting the crisis ..., 2011, str. 2). V ozadju radikalnejših prizadevanj je tudi nujnost bistvenega zmanjšanja celotnega ekološkega odtisa Evrope, ki nekajkrat presega planetarno sprejemljiv ekološki odtis na prebivalca. Tudi evropski minimalni ekološki cilji ( $3 \times 20)$ ne pomenijo upoštevanja biofizikalnih mej rasti, ampak nadaljevanje paradigme rasti na sicer nekoliko bolj sonaravno obarvanih predpostavkah. 
Treba pa je spremeniti oboje: ne samo tehnologijo, ampak tudi odpraviti količinsko ekonomsko rast ter z njo povezane vrednote in način življenja. Strategija EU se je po mnenju radikalnih ekološko-družbenih kritikov skrčila na neoliberalno politiko zaposlovanja in gospodarske rasti. Lizbonska strategija, predhodnica EU 2020, je v kriznem obdobju dejansko postala evropsko sanjarjenje o najbolj konkurenčnem, trajnostnem, rastočem gospodarstvu z novimi delovnimi mesti in večjo družbeno povezanostjo, zato je neslavno končala na papirnatem zgodovinskem smetišču. EU (in Slovenija) torej potrebuje nov, po našem mnenju trajnostno sonaravni razvojni in družbeni model, pa tudi zmanjšanje t. i. demokratičnega deficita in zmanjšanje družbenih, regionalnih razlik.

\section{TEORETIČNE ZASNOVE KONCEPTA SONARAVNEGA RAZVOJA}

Kako zasnovati naše bivanje in razvoj za napredek vseh prebivalcev, kako omogočiti varno in človeka vredno življenje vsem prihodnjim generacijam in celotni biosferi? Trajno rastoči dohodek že tako bogatih ljudi v svetu okoljskih omejitev ne more biti medgeneracijsko ustrezen cilj (Jackson, 2009, str. 6). Zgolj možni kratkoročni materialni napredek na račun naraščajoče degradiranosti okolja in povečevanja podnebnih sprememb in naraščajoče socialne ter medregionalne neenakosti ne morejo biti več osnovni cilji odgovorne, empatične civilizacije 21. st. Globalni družbeno-ekološki, sistemski prehod vsaj do srede 21 . st. je nujen in večplastno neobhoden. Trajno delovanje vseh materialnih dejavnosti znotraj nosilnosti okolja, ohranjanje celotne, mavrične ekosistemske mreže, prehod na obnovljive vire energije so temelji potrebnega okoljsko-podnebnega civilizacijskega prehoda, ki mora človekove kolonizacijske vzvode moči nad naravo ter model količinske rasti nadomestiti z vzvodi krožnega, ravnovesnega gospodarstva, zmernega materialnega blagostanja za vse prebivalce, praktičnega udejanjanja sočutja do prihodnjih rodov in drugih vrst.

Pri oblikovanju večplastno (ekonomsko, socialno in okoljsko) uravnotežene razvojne strategije države je ključno naslednje vprašanje: v kolikor družba postavlja kot cilj maksimizacijo širše pojmovanega blagostanja za vse generacije (sedanje in prihodnje), kakšna naj bo časovna alokacija naravnih virov (Harou in sod., 2002). S klasičnimi ekonomskimi analizami gospodarske rasti in modeli razvoja linearne progresije (trajna in naraščajoča količinska rast) v sedanjem obdobju pospešenega izčrpavanja tudi eksistenčno pomembnih naravnih virov in s tem povezanimi, planetarno prekomernimi okoljskimi pritiski ne moremo (več) odgovoriti na navedeno razvojno-varovalno dilemo. Po mnenju Rifkina (2010) potrebujemo v 21. st. radikalno drugačen vrednostni pogled (empatijo) glede organizacije naših gospodarskih, družbenih in okoljskih razmer, saj se pospešeno približujemo globalnemu entropijskemu kolapsu. Vse vlade bodo morale uporabljati nove, decentralizirane energetske in gospodarske modele, npr. za minimizacijo emisij toplogrednih plinov, saj se obdobje fosilnih goriv nepovratno zaključuje (Rifkin, 2010, str. 517).

Ena izmed teoretično vse bolj dodelanih razvojnih alternativ je model trajnostnega razvoja, ki ima sicer zelo različne definicije in vse bolj številne zlorabe. Trajnostni razvoj razumemo kot večplastni dvig blagostanja prebivalcev, torej odgovoren dvig materialnega, 
socialnega in okoljskega blagostanja sedanjih generacij na celotnem planetu brez ogrožanja eksistenčnih pogojev prihodnjih generacij in celotne biosfere (Hanžek in sod., 2010; Plut, 2014). Koncept trajnostnega razvoja ali koncept blaginje v širšem pomenu besede prehaja iz sedanjega ozkega koncepta ekonomskega razvoja v širši koncept kakovosti življenja, blagostanja. Poleg napredka na področju zagotavljanja ekonomskega standarda zajema še napredek na področju družbene blaginje in varovanja okolja ter medgeneracijsko odgovornost (Murn, 2013, str. 62). Obenem pa sustainability kot načelo postavlja trajnost razvoja kot njegovo odločujočo, bistveno potezo, zato je trajna rast proizvodnje in porabe nevzdržna (Vogrinec, 2013, str. 115).

Okoljska trajnost je ključno, inovativno vsebinsko polje medgeneracijsko odgovornega razvoja, zato je za njeno doseganje potrebna sonaravna organizacija bivanja in gospodarstva. Okoljsko zasnovan razvojni model ne pomeni zgolj ohranjanja narave, temveč tudi trajno (trajnostno) zaščito baze naravnih virov, ustvarjanje socialno občutljive družbe človeka vrednega blagostanja, ki živi v harmoniji z naravo (Baker, 2006). Sonaravni razvoj pojmujemo kot razvoj, ki je čim bolj skladen z naravo, z zmogljivostjo okolja, tako glede trajne oskrbe prebivalstva $z$ naravnimi viri kot glede sposobnosti nevtralizacije različnih okoljskih obremenitev.

Pomembno polje sonaravnega razvoja v širšem pomenu je tudi sonaravna raba regionalnih in lokalnih razvojnih potencialov. Endogeni (regionalni) razvoj je zasnovan na aktiviranju značilnih in/ali ustreznih notranjih virov in potencialov nekega območja, na povečanju in rabi lokalnih endogenih virov (Potočnik Slavič, 2010, str. 32-33). Sprememba razvojne paradigme $\mathrm{v}$ smeri trajnostnosti naj bi vodila tudi k spodbujanju endogenih razvojnih potencialov, npr. podeželja. Podčrtati velja, da so bile v dosedanjem regionalnem razvoju v ospredju vedno tiste vrste razvojnih potencialov (kapitalov), ki so imele povsem neposredno uporabno vrednost. $\mathrm{V}$ veliki meri pa so bile prezrte vrste kapitalov s posredno uporabno vrednostjo in pa t. i. kapitali z vrednostjo neuporabe (npr. 'brezplačne' ekosistemske storitve, biotska raznovrstnost) (Lampič, Mrak, 2008). Širše prepoznavne vrednote in številne prezrte vrednosti naravnega kapitala, ekosistemskih storitev se postopoma vključujejo v politike odločanja (Daily in sod., 2012).

Zaradi številnih okoljsko pozitivnih posledic je umestno obravnavati povečevanje samooskrbe kot eno od ključnih polj širše pojmovanega sonaravnega razvoja in s tem tudi trajnostnega razvoja. Zlasti povečanje prehranske, vodne in energetske samooskrbe držav in regij postaja obenem pomembna stranica endogenega regionalnega razvoja. Vodna, prehranska, energetska in okoljska (ekosistemska) varnost so hkrati pomembne sestavine širše pojmovane nacionalne in globalne varnosti 21. st. Okoljsko in etično zasnovano zarisovanje prihodnosti poudarja potrebno zadovoljevanje (zgolj) ključnih materialnih potreb vsem prebivalcem brez ogrožanja prihodnjih generacij in varno stopnjo nacionalne in regionalne samooskrbe z eksistenčno pomembnimi okoljskimi viri (Plut, 2013). Sonaravno gospodarstvo naj bi torej med drugim pomembno označevala raba lokalnih naravnih virov in decentralizacija produkcije zaradi potrebe po večji samooskrbi (Stutz, Warf, 2005, str. 114).

Številni strokovnjaki sodijo, da bo med okoljskimi viri voda postala ključna strateška dobrina 21. st., tudi zaradi pričakovanih učinkov podnebnih sprememb na vodne 
bilance držav in regij. Spremembe v razpoložljivosti vode zaradi podnebnih sprememb bodo bistveno vplivale na opravljanje številnih ekosistemskih storitev, na različne potrebe po vodi, kmetijsko proizvodnjo in prehransko varnost (Lawler in sod., 2011). Koncept prehranske varnosti vključuje sposobnost zagotavljanja hrane tudi v izrednih in kriznih razmerah, varno stopnjo potencialne samooskrbe in sledljivost neškodljivo pridelane kmetijske proizvodnje (Perpar, Udovč, 2010). Prihodnost globalne prehranske varnosti bo po mnenju Browna (2005, str. 185) odvisna od hkratne stabilizacije ključnih kmetijskih virov, ne le kmetijskih zemljišč, temveč tudi vodnih virov in svetovnega podnebnega sistema.

Krepitev energetske samooskrbe na ravni držav in regij povečuje geopolitično varnost države, možnosti rabe lokalnih obnovljivih virov energije in s tem povezano odpiranje številnih novih zelenih delovnih mest $\mathrm{z}$ višjo dodano vrednostjo. Sodobne tehnologije rabe obnovljivih virov energije (zlasti sončne energije) omogočajo, da milijoni stavb postanejo neto proizvajalci energije, ne pa eden od njenih največjih porabnikov (porabijo 30-40 \% vse energije in proizvedejo temu primeren delež toplogrednega $\mathrm{CO}_{2}$ ). Vodik pa bi moral po mnenju Rifkina (2010, str. 520) s pomočjo elektrolize postati ključni shranjevalec vseh oblik obnovljive energije, saj po njegovi energetski rabi ostaneta zgolj voda in toplota. Drugi načrtovalci stavijo na druge možne shranjevalce s pomočjo Sonca proizvedene energije.

Globalni trg okoljskih proizvodov in storitev naj bi do leta 2020 od 1000 milijard evrov narasel na 2000 milijard evrov (Green jobs and ..., 2013, str. 38). Zeleno gospodarstvo naj bi bilo nizkoogljično in učinkovito v rabi virov, ključen naj bi bil prehod od linearnega h krožnemu gospodarstvu. Rast, dohodki in zaposlenost naj bi bili spodbujeni s ciljnimi javnimi in privatnimi investicijami, razvojnimi politikami in zakonodajnimi spremembami, ki bi hkrati zmanjšale emisije in druge okoljske pritiske. Zelene tehnologije in zelene ekonomije so nujne, a niso brez neželenih in nepredvidljivih posledic. Velika iluzija je, če se teh ne vidi ali pa se jih ne prizna in celo prikriva. Sedaj se veliko govori in piše o 'zeleni rasti' in 'zelenem gospodarstvu'. Da bi 'zeleno gospodarstvo' nadomestilo obstoječe, mora rasti. Nobena rast in tudi ne zelena pa ne more biti trajna, opozarja Kirn (2012). Rast, ki temelji na uničevanju okolja, financiranju potrošnje z zadolževanjem, izkoriščanju redkih naravnih virov brez povratnega investiranja donosov, ni trajnostna (Murn, 2013, str. 49). Velika iluzija je misliti, da bo trajna 'zelena rast' stopila na mesto tradicionalne eksponentne rasti. Tudi zelena 'rast' se bo morala ustaliti znotraj ekofizičnih omejitev okolja, naravnih virov. Gospodarska rast je namreč povezana z rastjo rabe naravnih virov in zato prispeva $\mathrm{k}$ prekoračitvi okoljskih danosti planeta. Zelena ekonomija naj bi izboljšala človekovo blagostanje in socialno pravičnost in hkrati pomembno zmanjšala okoljska tveganja. Naravni kapital se v zeleni ekonomiji obravnava kot pogosto temeljna oblika ekonomskih kapitalov (ustvarjeni, finančni, človeški in socialni kapital), ki pomembno vpliva na ustvarjanje dohodkov. Sedanje politične, finančne, podjetniške, naravoslovne in tehnične elite ne verjamejo, da bi nas tudi vzdržna in ne samo eksponentna klasična industrijska rast vodila v družbeno-ekološki propad. Oklepajo se gesla »Ekonomska rast ali nazadovanje« (Kirn, 2012). Treba bo hkrati doseči biosfersko zavest in globalno empatijo ter se še pravočasno izogniti planetarnemu kolapsu (Rifkin, 2010, 
str. 616). Tretja industrijska revolucija zahteva nov pristop k pojmovanju biosfere, globalizacije, zahteva spremembe v izobraževanju, pristop k odločanju od spodaj navzgor.

Ker so obnovljivi viri energije več ali manj enakomerno razporejeni po svetu, ima vsaka regija dovolj virov, da je relativno samozadostna in trajnostna v svojem življenjskem slogu in hkrati s pomočjo pametnega omrežja povezana z drugimi regijami. Številna evropska mesta, regije in države (npr. Avstrija, Nemčija in Danska) so se odločile, da bodo čim prej dosegle ali celo presegle $100 \%$-no energetsko samooskrbo s pomočjo domačih, decentraliziranih obnovljivih virov energije na področju pridobivanja električne energije, ogrevanja zgradb in prometa (From vision to action, 2013). Avstrijska Koroška je sprejela strateški cilj, da bo na področju oskrbe z električno energijo in toploto do leta 2025 postala energetsko samooskrbna zgolj s pomočjo domačih obnovljivih virov energije (hidroenergija, sončna energija, biomasa, vetrna energija) in hkratnih ukrepov za zmanjšanje rabe energije (Energiemasterplan ..., 2014).

Trajnostni razvoj kot zgolj 'zelena ekonomija', oziroma do okolja prijazno gospodarstvo, ni dolgoročna rešitev, saj dejansko ostaja znotraj okvirov klasičnega razumevanja ekonomije in znotraj modela gospodarske rasti (t. i. 'zelena rast'). Po mnenju Omladiča (2011) tako razumljena zelena ekonomija sicer priznava okoljske omejitve in stavi na racionalnejše upravljanje omejenih virov (npr. raba obnovljivih virov energije), toda merilo njene uspešnosti je ekonomska uspešnost in gospodarska rast v konvencionalnem pomenu besede. Radikalnejša in okoljsko korektna razlaga pojma 'zelena ekonomija' pa izhaja iz kritike gospodarske rasti kot take, saj je trajno nevzdržen že sam imperativ gospodarske rasti. Koncept trajnostno sonaravnega razvoja (znotraj zmogljivosti, nosilnosti okolja) zavrača stalno (količinsko) rast gospodarstva in hkrati poudarja potrebo povečanja okoljsko sprejemljivega načina samooskrbe s ključnimi obnovljivimi okoljskimi viri. Krepitev regionalnega gospodarstva, povečevanje lokalne samooskrbe je nujen antipod globalizaciji in ključno trajnostno gospodarsko polje. Dejstvo je, da npr. tržne cene dostavljene hrane iz zelo oddaljenih območij ne odražajo realnih oportunitetnih, okoljskih in 'ogljičnih' stroškov prevoza.

Regionalno podjetništvo povečuje gospodarsko stabilnost in zaposlovanje, omogoča razvoj obrti, trgovanja in manjših podjetniških storitev ter tesnejše povezave med kupci in lokalnimi proizvajalci hrane. Zlasti raba razpoložljivih obnovljivih virov energije okrepi ekonomsko moč kmetij in lokalnega gospodarstva (Elliott, 2003). Decentralizacija podjetniških dejavnosti mora vključevati spodbude za lokalno trgovanje, lokalne storitve. Tudi solidarnostno zasnovano podjetništvo, različne oblike socialnega in družbeno odgovornega lokalnega in regionalnega podjetništva, krepitev socialnega kapitala mora država podpirati, kolikor je le mogoče. Lokalne skupnosti praviloma znajo oplemenititi pridobljena evropska in državna sredstva, če gre za lokalnim razmeram prilagojen izbor razvojnih projektov.

Zelena delovna mesta bodo ključni ekonomski motor, ko bo svet začel hitreje vstopati v nizkoogljično gospodarstvo (Renner, Sweeney, Kubit, 2009). Strokovnjaki posebej opozarjajo na velik zaposlitveni potencial trajnostne energetike. Tako naj bi doseganje $20 \%$-nega deleža obnovljivih virov energije v skupni energetski bilanci EU do leta 2020 odprlo okoli 600.000 zelenih delovnih mest. Skupaj z 20 \%-nim povečanjem energetske učinkovitosti 
naj bi v EU do leta 2010 nastalo več kot milijon novih zelenih delovnih mest (Green jobs and ..., 2013), kar je bilo tudi doseženo. Pospešen prehod na obnovljive vire energije in varčevanje $\mathrm{z}$ energijo bosta $\mathrm{v}$ prihodnosti ustvarila stotisoče novih delovnih mest, kar velja tudi za ozelenjeno gradbeništvo, okolju prijaznejšo avtomobilsko industrijo, kmetijstvo, strojegradnjo, turizem, lesno industrijo itd. Drugi ekonomski in zaposlitveni motor pa bodo po mnenju sociologa Hanžka in sod. (2010) dejavnosti nematerialne blaginje. Produktivno je tako delo v materialni proizvodnji, a enako ustvarja novo vrednost in dviguje BDP tudi 'nematerialna' proizvodnja, storitve, javni sektor. Kapital ima pri tem manjšo vlogo (financiranje mora temeljiti na participaciji prebivalstva na podlagi solidarnosti in vzajemnosti), $\mathrm{v}$ prvi plan mora stopiti država z načrtovanjem objektivnih pogojev za zadovoljevanje nematerialnih potreb in njihove dostopnosti za vse prebivalce, seveda v okviru finančnih zmogljivosti. Potrebna je tudi korenita sprememba kazalcev napredka države, saj je npr. BDP zgolj kazalec vrednosti vseh gospodarskih aktivnosti, a ne razlikuje med dejavnostmi, ki izboljšujejo ali poslabšujejo kakovost življenja (Rifkin, 2010).

\section{SONARAVNI IN SAMOOSKRBNI RAZVOJNO-VAROVAL- NI POTENCIALI SLOVENIJE}

Z vidika trajnostno sonaravnega razvoja označujejo Slovenijo stabilizacija prebivalstva in prebivalstvenih pritiskov na okolje in prostor, manjša mesta, velika razpršenost poselitve in majhnost naselij, bogati vodni viri, za evropske razmere zelo ohranjena narava in kakovostno bivalno okolje na pretežnem delu ozemlja. Našo državo odlikuje izjemna pokrajinska in biotska raznovrstnost, a tudi čezmerna poraba naravnih virov in različne oblike obremenjevanja okolja ter prostora, vključno s prisotnostjo prostorsko zaokroženih območij intenzivne in večplastne pokrajinske degradiranosti. Tudi Poročilo o razvoju (2013) in osnutek Strategije razvoja Slovenije za obdobje 2014-2020 (2013) ugotavljata prepočasno uveljavljanje načel trajnostnega razvoja, veliko energetsko intenzivnost in šibko integracijo okoljskih, socialnih in gospodarskih vidikov razvoja. Na področju okoljske stranice trajnostnega razvoja Slovenija ni v zadostni meri sledila ciljem trajnejšega zmanjševanja pritiskov na okolje in zaustavitve upadanja biotske raznovrstnosti. Obenem so se ponovno povečale razvojne razlike med slovenskimi regijami, vse regije so po letu 2008 povečale razvojni zaostanek za evropskim povprečjem, najbolj Koroška regija (Strategija razvoja Slovenije ..., 2013). Strukturo urbanega sistema je spremljala krepitev zgolj nekaterih večjih mest, močna suburbanizacija in pospešena dnevna migracija po avtocestnem križu.

Slovenija na planetarni in številnih regionalnih ravneh presega nosilnost geografskega okolja, ekološki odtis Slovenije na prebivalca je skoraj dvakrat večji od njene biološke zmogljivosti. Po metodologiji ekoloških odtisov glede na zmogljivost biološko produktivnih zemljišč planeta namreč Slovenija dvakratno presega planetarno sprejemljivo porabo naravnih virov, po metodologiji okoljskega prostora pa za faktor 3-4 (Plut, 2014). Snovna, energetska in emisijska intenzivnost gospodarstva (emisije na enoto BDP) je ostala velika (Strategija razvoja Slovenije ..., 2013). 
Številna slovenska mesta označuje čezmerna onesnaženost, zlasti onesnaženost zraka s prašnimi delci, zamuja projekt čiščenja odpadnih voda, javni promet še vedno nazaduje, namesto strategije države brez odpadkov se načrtuje gradnja ene ali dveh velikih sežigalnic (Ljubljana in Maribor). Slovenska mesta so zaradi splošne šibke prevetrenosti in pogostih temperaturnih inverzij zelo občutljiva na obremenjevanje ozračja (Ogrin, Vintar Mally, 2013). Nadaljevanje trendov prinaša slabšanje kakovosti bivalnega okolja in življenja, zmanjševanje okoljskega kapitala za trajnostni razvoj, upad širše pojmovane blaginje. Kljub nekaterim pomembnim okoljskim rezultatom želeni dvig količinske materialne blaginje še vedno poteka na račun izčrpavanja okoljskega kapitala Slovenije in njenih pokrajin na račun prihodnjih generacij. Tudi ukrepi izhoda iz krize niso usmerjeni $v$ hkratno načrtovanje povečanja materialne blaginje in zmanjševanja pritiskov na okolje, $v$ trajnostno nujne strukturne spremembe $\mathrm{v}$ gospodarstvu, poselitvi, infrastrukturi in vsakdanjem načinu življenja.

Kljub določenim pozitivnim premikom pri zmanjševanju nekaterih pritiskov na okolje in izboljšanju kakovosti nekaterih sestavin okolja (npr. zraka) so podatki za Slovenijo z vidika planetarnih pritiskov na okolje na prebivalca neugodni in z vidika koncepta planetarne pravičnosti in ocene nosilnosti planeta bistveno previsoki. V letu 2050 bi bili namreč planetarni pritiski svetovnega prebivalstva ob ravni pritiskov na okolje prebivalca Slovenije na začetku 21. st. za 2,5-4-krat večji.

V industrijskem obdobju je Slovenija razpolagala zgolj s pičlimi domačimi viri (lignit, nekatere rude). Za prihodnje obdobje trajnostnega razvojnega modela pa Slovenija razpolaga s ključnimi strateškimi razvojno-varovalnimi in samooskrbnimi potenciali:

- raznovrstni ter bogati interni in tranzitni vodni viri;

- gozdni ekosistemi in drugi obnovljivi viri;

- obstoječa in potencialna (pred nekaj desetletji še v obdelavi) kmetijska zemljǐšca.

Kot pomemben okoljski vir velja izpostaviti tudi izjemno geografsko in biotsko pestrost Slovenije kot sestavino zdravega bivalnega okolja in zelo pomembnega naravnega turističnega potenciala.

\section{I. Raznovrstni ter bogati interni in tranzitni vodni viri}

Zaradi velike povprečne letne količine padavin, prevlade prepustnih kamnin (večji specifični odtoki) in reliefne razgibanosti se Slovenija v Evropi uvršča med države z bogatimi vodnimi viri. Specifični odtok je namreč za skoraj trikrat večji od evropskega povprečja. Ključni problemi rabe voda pa so neenakomerna prostorska razporeditev, sezonska spremenljivost količin vode, velika ranljivost podzemnih voda (temeljni viri pitne vode) in neustrezna kakovost rečne vode za pitje brez predhodnega čiščenja.

Preko in iz ozemlja Slovenije se pretaka na leto približno $32,1 \mathrm{~km}^{3}$ vode $(32,1$ milijarde $\mathrm{m}^{3} /$ leto); $59 \%$ predstavljajo interne rečne vode, $41 \%$ pa doteka iz Avstrije (Bat, Uhan, 2003). Analize trendov značilnih pretokov, ki veljajo za pretežni del Slovenije, kažejo na naraščajoči trend velikih pretokov in padajoči trend srednjih in malih pretokov. Znižujejo se torej srednji pretoki, pa tudi pretoki v sušnem delu leta, kar utegne postati problematično $\mathrm{z}$ vidika kmetijstva, vodne oskrbe in zmanjšanja samočistilnih zmogljivosti. 
Dolgoletni nizi podatkov o srednjih letnih pretokih kažejo na upadanje rečnega odtoka (Kazalci okolja ..., 2014). Razmerja med ekstremnimi pretoki večjih rek znašajo $1: 50$ (100) in več, kar kaže na večjo verjetnost poplav in hidroloških suš, povečanje ekološke občutljivosti in zmanjšanje turistične rabe tako v obdobju ekstremno visokih, kot ob ekstremno in povprečno nizkih (poletnih) pretokih. Razmerje med najbolj vodnatim (severozahod) in najbolj suhim (severovzhod) območjem Slovenije je pri odtokih $1: 16$ (pri padavinah $1: 5$ ), kar kaže tudi na velike regionalne razlike v zagotavljanju oskrbe s pitno vodo (Kazalci okolja ..., 2014). Slovenija je torej kot država zelo bogata z vodnimi viri, vendar so razlike v padavinah in odtokih zaradi geografske prehodnosti in pestrosti zelo veliki. Suša, pomanjkanje vode je torej tudi v Sloveniji problem, zlasti zaradi pomanjkanja padavin in njihove neugodne časovne razporeditve (Suhadolc in sod., 2010).

Po skupnih razpoložljivih in internih vodnih količinah na prebivalca se Slovenija uvršča med z vodo bogate evropske države, kar je brez dvoma pomemben, trajnostno sonaravni, strateški in gospodarski potencial. Letna količina rečne vode na prebivalca je bila v zadnjih letih nad $16.000 \mathrm{~m}^{3}$, (interne rečne vode: $9100 \mathrm{~m}^{3}$, svetovno povprečje: $6600 \mathrm{~m}^{3}$ ), kar pomeni najmanj dvakrat večje količine kot je evropsko povprečje. Po skupni letni količini vode na prebivalca se je Slovenija leta 2010 uvrščala na tretje mesto med članicami EU-27, takoj za Finsko $\left(21.268 \mathrm{~m}^{3}\right.$ ) in Švedsko $\left(16.667 \mathrm{~m}^{3}\right.$ ) (Avstrija $9616 \mathrm{~m}^{3}$, Italija $3325 \mathrm{~m}^{3}$, Nemčija $1878 \mathrm{~m}^{3}$ ) (Renewable internal freshwater ..., 2012). V letu 2008 je bilo v t. i. pripovršinskih vodonosnikih 21 teles podzemnih voda $565 \mathrm{~m}^{3}$ podzemne vode na prebivalca (Rejec Brancelj, Dobnikar Tehovnik, Uhan, 2011). V nekaterih evropskih državah (Madžarska, Nizozemska) je celo skupna količina vseh internih vod na prebivalca manjša kot je v Sloveniji količina podzemeljskih vod na prebivalca.

Slovenija se torej zaradi bogatih vodnih virov uvršča med evropske države, ki uporabljajo za vodno oskrbo zelo majhne deleže razpoložljivih vodnih virov, saj je primerljiva s sosednjo Avstrijo, Švico in Finsko. Slovenija je v obdobju 1997-2005 v povprečju letno načrpala zgolj 2-3 \% vseh razpoložljivih vod. Skupaj z Norveško, Islandijo, Latvijo, Slovaško, Švedsko, Irsko, Finsko in Romunijo se je uvrščala med države z najnižjim deležem načrpane vode (The European Environment ..., 2010). Uvršča se torej v zgornjo četrtino evropskih držav, kjer se v povprečju ne pojavljajo t. i. vodni stresi. $31 \%$ prebivalcev Evrope pa živi v državah, kjer količina načrpane vode že presega $20 \%$ internih vod, kar z ekosistemskega vidika še predstavlja sprejemljiv del uporabe, v nekaterih državah pa letna količina načrpane vode presega 40 \% (Madžarska, Moldavija). Vendar je potrebno upoštevati, da navedeni kazalci upoštevajo zgolj količino, ne pa tudi kakovosti internih (rečnih) vod. Rezultati kažejo, da lahko za 60 \% vodnih teles površinskih voda pričakujemo, da do leta 2015 ne bodo dosegla ciljev Vodne direktive, torej dobrega ekološkega in kemijskega stanja (Rejec Brancelj, Dobnikar Tehovnik, Uhan, 2011).

Slovenija je torej po splošni količini vode na prebivalca med najbolj bogatimi evropskimi državami. Po kazalcu rabe vodnih virov je Slovenija z okoli 3 \% v manjši skupini držav Evrope z najmanjšo rabo vodnih virov (Kazalci okolja ..., 2014). Kljub temu se tudi zaradi podnebnih sprememb in pričakovanih večjih potreb po namakanju pričakuje, da se bodo zlasti v jugozahodni in severovzhodni Sloveniji problemi s sezonskim hidrološkim in kmetijskim pomanjkanjem vode v vegetacijskem obdobju zaostrili. V prihodnosti 
bo zaradi možnega zniževanja gladine podzemnih voda in zmanjševanja pretokov v vodotokih $\mathrm{v}$ času vegetacije za okoljsko in vodno pretehtano večje namakanje kmetijskih površin mogoča predvsem raba vode iz večnamenskih vodnih zadrževalnikov (Suhadolc in sod. ..., 2010). Vendar je potrebno poudariti, da bo potrebno razen drugih porabnikov vode upoštevati tudi okoljevarstvene, naravovarstvene in varnostne omejitve gradnje večnamenskih, manjših vodnih zadrževalnikov.

Na državni ravni torej razpolaga Slovenija z bogatimi vodnimi viri, ki bodo tudi v primeru zaostrenih podnebnih razmer omogočali zanesljivo vodno oskrbo. Vendar nas sušno leto 2003 opozarja, da se lahko hidrološka in kmetijska suša pojavi na več kot polovici ozemlja Slovenije. Potrebna bo varčna poraba vode in zmanjševanje obremenjevanja vodnih virov, zlasti tekočih voda in območij talne vode (kmetijstvo, urbanizacija).

\subsection{Gozdni ekosistemi in drugi obnovljivi viri}

Med obnovljivimi viri je v Sloveniji zaradi izjemne dvoplastne surovinsko-energetske in ekosistemske vloge potrebno izdvojiti gozdne ekosisteme in njihovo lesno biomaso. Slovenija je z okoli 60 \%-no gozdnatostjo ozemlja na tretjem mestu med državami Evrope. V letu 2011 je bila povprečna lesna zaloga že nad $280 \mathrm{~m}^{3} / \mathrm{ha}\left(2012: 285 \mathrm{~m}^{3} / \mathrm{ha}\right)$, letni prirastek pa $7 \mathrm{~m}^{3} / \mathrm{ha}$, oziroma 8,3 mio. $\mathrm{m}^{3}$ lesa (Poročilo Zavoda za gozdove ..., 2012). Izvedeni posek je v letu 2011 znašal 3,90 mio. $\mathrm{m}^{3}$ od 5,50 mio. $\mathrm{m}^{3}$ možnega poseka po gozdnogospodarskih načrtih. V letu 2011 je bil dejanski posek 71 \% možnega poseka, v preteklih letih pa praviloma $40-50 \%$.

Po Pohlevnovem mnenju (2010) je les edina surovina v Sloveniji, ki je imamo v izobilju, saj letno priraste $4 \mathrm{~m}^{3}$ lesa na prebivalca, posekamo pa ga le slabo polovico. Energetska raba lesne biomase pa je hkrati najpomembnejši način rabe obnovljivih virov energije (pred vodno energijo). Lesna biomasa se izkorišča z razmeroma slabim izkoristkom in čezmernimi izpusti, zato je poleg spodbujanja zamenjave fosilnih goriv potrebno spodbujati tudi zamenjavo obstoječih sistemov za ogrevanje na lesno biomaso $\mathrm{z}$ učinkovitejšimi (Zelena knjiga ..., 2009). Podpreti je treba izkoriščanje lesne biomase kot vira energije $\mathrm{v}$ lokalnih energetskih sistemih in za soproizvodnjo toplote ter električne energije. Spodbujanje energetske rabe lesne biomase je treba povezati z razvojem lesnopredelovalne industrije in obrti, raba lesa kot dragocene surovine mora imeti prednost pred njegovo energetsko rabo (Humar, Kutnar, Piškur, 2013).

Količina biomase v slovenskih gozdovih narašča, zato je gozd (in gozdne prsti) v Sloveniji tudi ponor $\mathrm{CO}_{2}$. Prav predelava in raba lesa lahko bistveno prispevata $\mathrm{k}$ prehodu Slovenije v nizkoogljično družbo, vendar je predpogoj racionalen in smotrn sistem njegovega pridobivanja, predelave in rabe v vsej gozdno-lesni verigi (Humar, Kutnar, Piškur, 2013). Država mora opredeliti les kot strateško surovino in spodbuditi proizvodnjo lesnih izdelkov, npr. z zelenimi javnimi naročili. Po vzoru avtomobilske industrije moramo spodbuditi nakup novih izdelkov, narejenih iz lesa in drugih naravnih, obnovljivih virov, če kupec ob nakupu star izdelek zamenja s primernim novim.

Ocene teoretičnih in tehničnih (izkoristljivih) potencialov OVE (obnovljivih virov energije) Slovenije so sicer različne, vendar vse ocene za nekaj velikostnih razredov 
presegajo sedanjo in načrtovano rabo energije do leta 2020 (Plut in sod., 2004). Večina ocen poudarja, da razpolaga Slovenija z velikim teoretičnim potencialom OVE, obstajajo pa številne tehnološke, prostorske in okoljske omejitve, ki pa še vedno omogočajo, da bo Slovenija v prihodnosti lahko krila vse potrebe po energiji na sedanji ravni porabe in seveda tudi na ravni priporočene porabe po konceptu okoljskega prostora, ki do leta 2050 priporoča prepolovitev sedanje porabe energije (iz 3,5 toe na 1,5 toe na prebivalca), popolno opustitev rabe jedrske energije, zelo omejeno rabo fosilnih goriv in večkratno večjo rabo lastnih OVE. Po večini ocen teoretičnega in gospodarsko izkoristljivega potenciala OVE sta dolgoročno ključna domača vira ob hidroenergiji še sončna in geotermalna energija. Večji pomen se obeta tudi biomasi in hidroenergiji, zelo omejen pa vetrni energiji, saj so na splošno vetrovne razmere na zatišni strani Alp z energetskega vidika skromnejše. Obstajajo pa tudi naravovarstveni zadržki, saj so vetrovno najbolj primerne lokacije praviloma $\mathrm{v}$ varovanih območjih. Tudi gradnja in delovanje malih hidroelektrarn povzročata dokazane negativne okoljske vplive, vključno npr. z vplivi na populacijo potočne postrvi (Cokan, Repe, 2013). V zadnjih letih se pojavljajo po svetu poskusi rabe toplotnih vodonosnikov pod $100{ }^{\circ} \mathrm{C}$ ob pomoči dodatnega obnovljivega vira tudi za proizvodnjo električne energije, kar je zlasti obetavno za severovzhodno Slovenijo.

Slovenijo označuje velika poraba energije in uvozna odvisnost ter velik prispevek energetike k obremenjevanju okolja. Kljub navedenemu dejstvu smo tudi po letu 2007 priča neugodnim gibanjem na področju energetske intenzivnosti, kar je še posebej problematično, ker je raba energije na enoto bruto domačega proizvoda v primerjavi z državami EU (predvsem zaradi obsežne rabe goriv v cestnem prometu) visoka. V obdobju 19952008 se je delež OVE v celotni porabi energije v povprečju držav EU povečeval hitreje kot v Sloveniji. V letu 2009 in 2010 se je delež rabe OVE v Sloveniji povečeval hitreje kot v EU. V letu 2011 pa je delež OVE znova nekoliko upadel in je znašal okoli 14 \%, kar pa je bilo nad evropskim povprečjem, ki je znašalo 9 \% (Poročilo o razvoju, 2012).

V Sloveniji v strukturi rabe OVE še vedno močno prevladujeta raba lesa in hidroenergija. Na začetku 21. st. sta bili hidroenergija in biomasa dejansko najpomembnejša OVE, njuna izkoriščenost od gospodarsko izkoristljivega potenciala pa je bila okoli 40-50\%. Podčrtati velja, da so tudi pri rabi hidroenergije in biomase številne, zlasti naravovarstvene omejitve. Slovenija uporablja okoli polovico tehnično izkoristljivega hidroenergetskega potenciala, zaradi okoljevarstvenih (Mura, Soča), prostorskih, kmetijskih in drugih omejitev pa bi bilo v prihodnje ob vseh omejitvah možno povečati rabo Save in manjših vodotokov na lokacijah nekdanjih obratov na vodni pogon, ki jih je bilo v preteklosti okoli 4000. V zadnjih letih pa se je povečala raba geotermalne energije in zlasti sončne energije (zlasti pri proizvodnji električne energije s pomočjo sončnih elektrarn). Doseganje zavez EU do leta 2020 bo tako zahtevalo nadaljnje ukrepe za spodbujanje rabe OVE in tudi njihovo učinkovitejšo rabo.

Po mnenju Novaka in Tomšiča (2004) je ustvarjanje novega decentraliziranega, sonaravno trajnostnega energetskega sistema velika priložnost tudi za znanstveni in tehnološki razvoj v Sloveniji, počasnost odziva pa je lahko usodna in etično sporna. Za udejanjanje globalno in lokalno zasnovanega trajnostnega sonaravnega razvoja mora Slovenija razen hitre stabilizacije porabe energije povečati rabo svojih obnovljivih virov (vključno z rabo 
vetrne in vodne energije, pa tudi biomase, sončne in geotermalne energije), vendar na lokacijah, ki so ne samo kar najbolj donosne, temveč tudi okoljsko in socialno optimalne ter lokalno družbeno sprejemljive.

Politično in lokalno izsiljena ter finančno netransparentna gradnja 6. bloka TE Šoštanj in okrepljeni glasovi za gradnjo drugega bloka JE Krško pomenijo pritiske za nadaljevanje še bolj okrepljenega fosilno-jedrskega scenarija in s tem povezano nadaljnje povečevanje rabe električne energije. Tako Slovenija ne bo izkoristila dveh ključnih razvojnih dejavnikov - inovativnega znanja zlasti mlade, izobražene generacije in regionalnih, zlasti naravnih virov na celotnem ozemlju države.

Nasprotno pa bi udejanjanje verjetno najprej sonaravno šibkega, po letu 2020 pa tudi sonaravno močnega decentraliziranega elektroenergetskega scenarija stabilizacije in zmanjševanja rabe energije Sloveniji omogočilo sicer najprej počasnejši dvig blagostanja, a okrepljeni policentrični in sonaravni razvoj. Hkrati bi decentralizirana proizvodnja OVE povečala stopnjo samooskrbe in zaposlitve ter zanesljivega dohodka prebivalcev $\mathrm{v}$ vseh regijah, ki razpolagajo z različnimi obnovljivimi viri. Vendar velja poudariti, da tudi udejanjanje šibke in močnejše energetske regionalne sonaravnosti prinaša določene okoljske pritiske, ki pa jih je tudi zaradi regionalno razpršenega vzorca objektov proizvodnje iz obnovljivih virov energije lažje prilagajati zmogljivosti okolja.

Ključni trajnostni pogoj za večjo spremembo energetske politike so spremembe v ravnanju porabnikov energije, energetski zasuk pa je odvisen od politične odločitve, od stopnje ekologizacije celotnega razvojnega modela. Ključne usmeritve trajnostno sonaravno 'zmerne' energetske strategije Slovenije do leta 2030 naj bi bile:

- zmanjševanje rabe primarne energije (s 7,2 mio. toe $v$ letu 2011 na okoli 6,4 mio. toe v letu 2020 in na okoli 5 mio. toe v letu 2030) in končne energije s poudarkom na pospešenem izboljševanju energetske učinkovitosti (izboljšanje vsaj za okoli 2,0 \% na leto; zmanjšanje energetske intenzivnosti z 297 toe/mio. evrov BDP na manj kot 200 toe/mio. evrov BDP do leta 2025/2030; povprečje EU leta 2010: 200; Avstrija: 145);

- okrepljena vloga OVE, katerih tehnično izkoristljiv energetski potencial za več kot 40-krat presega porabo primarne energije $v$ letu 2010; razen hidroenergije in lesne biomase bistveno večja vloga sončne (toplotna in električna energija) in geotermalne energije; najmanj 25-odstotni delež OVE v porabi končne energije (2011: 19,9\%) do leta 2020 in 40-odstotni do leta 2030;

- stabilizacija porabe električne energije in več kot 50-odstotni delež proizvedene električne energije s pomočjo mavrice domačih OVE (2011-2012: 26-29\%) do leta 2030;

- najmanj $20 \%$-no (30 \%) zmanjšanje izpustov toplogrednih plinov do leta 2020 (2011: 19,5 mio. t oziroma okoli $10 \mathrm{t}$ toplogrednih plinov/preb.) in $40 \%$-no zmanjšanje do leta 2030 (na okoli $4 \mathrm{t}$ toplogrednih plinov/preb.);

- negradnja drugega bloka JE Krško in večja (prehodna) vloga zemeljskega plina (zlasti v soproizvodnji električne energije in toplote v večjih mestih) tudi po letu 2030 kot fosilnega goriva energetskega prehoda.

Slovenija in njene regije razpolagajo $\mathrm{z}$ mavrico decentraliziranih obnovljivih virov energije, ki po teoretičnem in tehnično izkoristljivem energijskem potencialu večkratno 
presegajo načrtovano rabo energije v prihodnjih desetletjih. Vendar bi morala Slovenija po konceptu okoljskega prostora in sonaravnih globalnih in EU scenarijih (npr. Greenpeacea) bistveno zmanjšati porabo primarne in končne energije. Obenem bi morala Slovenija fosilna goriva in jedrsko energijo do srede 21. st. skoraj v celoti nadomestiti z domačimi OVE, kar bi dejansko omogočilo uveljavitev sonaravnega koncepta energetske samooskrbe. Ob hidroenergiji naj bi do leta 2050 sončna in geotermalna energija (toplota in soproizvodnja električne energije) postali steber trajnostne sonaravne energetike Slovenije. Energetska raba lesa naj bi bila podrejena njegovi surovinski rabi, vendar velike lesne zaloge in prirastki omogočajo tudi pomembnejšo vlogo v energetskih bilancah, zlasti bolj gozdnatih regij Slovenije (sodobno individualno in daljinsko ogrevanje, soproizvodnja toplote in električne energije). Vetrna energija bo zaradi prevladujoče zavetrne lege Slovenije imela manjšo, omejeno vlogo. Predvsem severovzhodna Slovenija (zlasti Pomurje) razpolaga z večjim potencialom geotermalne energije, zato lahko pričakujemo, da bo v navedeni regiji (po izvedenih študijah) v bližnji prihodnosti začela obratovati prva geotermalna elektrarna v Sloveniji.

Po večini ocen teoretičnega in gospodarsko izkoristljivega potenciala OVE sta dolgoročno ob hidroenergiji ključna domača vira še sončna in geotermalna energija, delno tudi lesna biomasa. Pisana mavrica in zmogljivost regionalnih OVE omogočata ob smotrni rabi, zmanjšani porabi energije vsem slovenskim regijam in Sloveniji kot državi doseganje trajne energetske neodvisnosti, energetske samooskrbe.

Varčna raba električne energije, vztrajno zmanjševanje njene proizvodnje in porabe, bistveno večja domača proizvodnja električne energije s pomočjo okoljsko pretehtanih načinov rabe mozaika OVE sta ključna stebra udejanjanja sonaravnih elektroenergetskih in drugih energetskih inačic. Sodimo, da zgolj scenarij močnejše, bolj decentralizirano in energijsko mozaično zasnovane energetske sonaravnosti in večje samozadostnosti Slovenije do leta 2030 omogoča okvirno uveljavitev radikalnejšega koncepta okoljskega prostora do leta 2050, ko naj bi se planet in države sveta tudi na energetskem polju zelo približale razvoju v okviru ekosistemskih zmogljivosti okolja in okoljskih virov.

\subsection{Obstoječa in potencialna kmetijska zemljišča}

Zaradi naravnih razmer je za Slovenijo značilna prevlada gozdnih površin, ki so po različnih ocenah leta 2010 (različni metolodoški pristopi) obsegale 60-66 \% ozemlja, leta 1876 pa le 36,4 \% ozemlja Slovenije. Kmetijske površine so leta 2010 obsegale 28 \% ozemlja, značilen pa je dolgoletni trend zmanjševanja. Večji del kmetijskih zemljišč je v območjih z omejenimi naravnimi pogoji za kmetovanje (Poročilo o stanju kmetijstva ..., 2012).

Okoli leta 1960 je bilo v Sloveniji okoli 300.000 ha njiv in vrtov ter leta 1991 okoli 200.000 ha, predvsem zaradi obsežnega zaraščanja in tudi zaradi pozidave. Leta 2009 je bilo le še 175.000 ha njiv in vrtov (od tega je bilo 101.000 ha žitnih in 54.000 ha površin za krmne rastline), oziroma pičlih $858 \mathrm{~m}^{2}$ obdelovalnih površin na prebivalca, leta 2010 pa 170.000 ha (leta 2011 pa zgolj 168.700 ha), oziroma le še $830 \mathrm{~m}^{2}$ na prebivalca. Slovenija je po obsegu kmetijskih obdelovalnih površin (njive in vrtovi) na repu držav članic EU, saj je med 27. državami uvrščena na 24. oziroma 25. mesto. Leta 2007 je bilo namreč 
samo še 8,6 \% obdelovalnih površin (leta 1900: 19 \%; leta 1953: 18 \% in leta 1991: 11 \%) ter $24,3 \%$ kmetijskih površin v uporabi glede na celotno površino države. Evropsko povprečje je bilo leta $201024,0 \%$ obdelovalnih oziroma 37,0 \% skupnih kmetijskih površin v uporabi (Key figures ..., 2013; Suhadolc in sod., 2010).

Leta 2010 je bilo po podatkih SURS in po popisu kmetijstva 474.432 ha kmetijskih zemljišč v uporabi oziroma $2350 \mathrm{~m}^{2} /$ prebivalca. $V$ geografsko in klimatsko podobnih razmerah bi za varno prehransko oskrbo v Sloveniji potrebovali na prebivalca okoli 2500$3000 \mathrm{~m}^{2}$ obdelovalnih kmetijskih zemljišč (njiv, travnikov in sadovnjakov). V Sloveniji smo torej že pod navedeno mejo (Hrustel Majcen, 2004; Suhadolc in sod., 2010).

Stopnja samooskrbe Slovenije je zlasti pri rastlinskih pridelkih zelo odvisna od letine, ki je pogojena $\mathrm{z}$ vremenskimi razmerami. V obdobju 2006-2010 je bila stopnja samooskrbe z žiti nekaj nad $50 \%$, leta 2011 pa se je povečala na $69 \%$, zlasti na račun krmnega žita (Poročilo o stanju kmetijstva ..., 2012). Kljub temu velja podčrtati, da je stopnja samooskrbe s prehransko zelo pomembno pšenico leta 2011 znašala zgolj $55 \%$, a je bila za $13 \%$ večja v primerjavi s povprečjem v obdobju 2006-2010. Najnižja je bila stopnja samooskrbe s svežo in predelano zelenjavo, ki je leta 2010 znašala $31 \%$, leta 2011 pa $37 \%$. Pri živalskih proizvodih so bile v obdobju 2006-2011 stopnje samooskrbe višje, pri mesu v povprečju med 83 in $100 \%$ (pri prašičih le še okoli 50 \% v letu 2011), pri jajcih okoli $95 \%$ in pri mleku okoli $115-120 \%$.

Kljub zelo nizki stopnji prehranske oskrbe velja podčrtati, da Slovenija razpolaga z dovolj velikimi potenciali kmetijskih zemljišč, da lahko varnostno tvegano, zelo nizko stopnjo splošne prehranske samooskrbe (okoli 50 \% leta 2010) bistveno povečamo (na 75-80 \%) in npr. pri pšenici doseže popolno samooskrbo (Plut, 2013). To pomeni, da moramo kmetijske površine dejansko povečati na stanje okoli leta 1960, jih skoraj izključno nameniti pridelavi ekološko neoporečne hrane (kljub nekoliko manjšim pričakovanim donosom, delno tudi zaradi slabših naravnih razmer na dveh tretjinah kmetijskih zemljišč), manj pa pridelavi živalske krme in zelo omejeno pridelavi oljnih rastlin za gorivo (skoraj izključno na zastrupljenih oziroma drugače degradiranih površinah).

Za zagotavljanje prehranske varnosti Slovenije sta v obdobju stabilizacije njenega prebivalstva ključna naravna predpogoja zadosten obseg kakovostnih kmetijskih zemljišč in ohranjanje rodovitnosti prsti. Cilj pa je ne le ohranjanje najbolj rodovitnih kmetijskih zemljišč, temveč njihovo povečevanje, še posebej njivskih, zlasti žitnih površin. Tudi z vidika ohranjanja naravne rodovitnosti prsti in kakovostne vodne oskrbe bi bilo potrebno zlasti na vodovarstvenih in zavarovanih območjih povečati površine za ekološko pridelavo hrane. Delež kmetijskih površin v uporabi z ekološko pridelavo se sicer povečuje. Od leta 2005 do leta 2012 se je njihov delež povečal s $4,5 \%$ na $7,3 \%$, vendar je še daleč od zastavljenega cilja (15 \% ekološko obdelanih kmetijskih zemljišč do leta 2015) (Kazalniki zelene rasti, 2014).

Z vidika prehranske varnosti je nedopustno spodbujanje pridelovanja koruze za potrebe bioplinarn in raba odpadne gnojevke na ekološko zelo občutljivih zemljiščih ter gojenje drugih poljščin za proizvodnjo biodizla na najboljših kmetijskih površinah. Večjo skrb in sredstva pa bo potrebno nameniti povečanju sonaravne, učinkovite rabe vode za namakanje (manjši zadrževalniki vode). Ohranjanje obstoječih in, zgodovinsko 
gledano, ekosistemsko in poselitveno zelo premišljeno ponovno povečanje kmetijskih zemljišč (zlasti zaraščenih površin) sta torej ključna pogoja za dosego varne stopnje samooskrbe Slovenije s hrano (Plut, 2012). Dejstvo je, da je Slovenija prešla iz razmerja $50 \%$ gozdov in $50 \%$ ostalih površin v petdesetih letih 20 . st. na razmerje $60: 40 \% \mathrm{~V}$ korist gozdov okoli leta 2010.

\section{SONARAVNA GOSPODARSKA USMERITEV SLOVENIJE}

Slovenija se v naslednjih letih lahko razvija po dveh razvojnih konceptih, neoliberalnem ali trajnostno sonaravnem. Po mnenju ekonomistke Murnove (2013) ima Slovenija dovolj razvojnih potencialov, da se iz krize reši sama in se načrtno, strateško usmeri na pot dolgoročnega uravnoteženega in trajnostnega razvoja, v smeri razvojnega koncepta blaginje $\mathrm{v}$ širšem pomenu. Z vidika potenciala naravnih virov je za Slovenijo ključna in priporočena gospodarska usmeritev v smeri zmanjševanja porabe energije in snovi ter decentralizirane, regionalne rabe mavrice domačih obnovljivih virov. Sonaravna vizija in strategija razvoja Slovenije mora biti razen $v$ svet usmerjena tudi v čedalje manjšo odvisnost, torej v krepitev človekove in nacionalne samozadostnosti, zlasti glede na tiste vidike življenja, brez katerih človek ne more preživeti: krepitev prehranske, energetske, vodne in drugih vrst samozadostnosti. Zato je za Slovenijo razen skladnejšega regionalnega razvoja ključna in priporočena trajnostna, sonaravna gospodarska usmeritev. Okoljske tehnologije in ozelenjeno podjetništvo, okoljsko odgovorna raba domačih okoljskih virov, sonaravno kmetijstvo, turizem, promet (tirni in javni, kolesarjenje) in gradbeništvo (energetska prenova zgradb, pasivna gradnja, domači gradbeni materiali) ter ekologizirane druge dejavnosti naj postanejo jedro slovenskega inovacijskega, trajnostnega razvojno-okoljskega preboja.

Izdelati in udejanjati je treba dodatne nacionalne trajnostne razvojne projekte za:

- sonaravno bivanje s podporo nastajanja pilotnih vzorčnih ekovasi in urbanih ekososesk;

- povečanje prehranske in energetske samooskrbe Slovenije, njenih regij in občin (pilotne vzorčne samooskrbne občine);

- sonaravno gospodarjenje in rabo lokalnih virov v različnih tipih varovanih območij Slovenije;

- sonaravni razvoj turizma na podeželju in v mestih;

- prilagajanje celotnega gospodarstva, poselitve, načina življenja podnebnim spremembam;

- ekoremediacije kot osnovne sonaravne metode za zmanjšanje in preprečevanje netrajnostnih načinov bivanja in gospodarjenja na državni, zlasti pa na regionalni in lokalni ravni.

Globalizirano slovensko gospodarstvo čaka do leta 2020 s strateškega vidika na okoljsko-razvojnem področju zlasti:

- temeljita energetsko-okoljska prevetritev v smeri nizkoentropijske in nizkoogljične družbe, zasnovane razen na prilagajanju podnebnim spremembam še na zahtevnem sodelovanju pri udejanjanju podnebno-energetskega svežnja EU do leta 2020: $20 \%$-no zmanjšanje izpustov toplogrednih plinov, $20 \%$-no povečanje energetske učinkovitosti in povečanje rabe obnovljivih virov na $20 \%$ končne porabe energije; 
- pospešeno prepoznavanje in vključevanje vseh okoljsko-podnebnih zunanjih stroškov $\mathrm{v}$ cene proizvodov in storitev, kar bo med drugim bistveno spremenilo razmerja cen virov energije in ekosistemskega pomena bioproduktivnih zemljišč;

- večji prispevek slovenskega gospodarstva pri iskanju trajnostno optimalnih sodobnih izzivov širše pojmovane nacionalne varnosti, katere pomembne sestavine so vodna, podnebna in prehranska varnost (težnja $\mathrm{k}$ samooskrbi, ohranjanje že strateško kritičnega razmerja med kmetijskimi, gozdnimi in pozidanimi površinami!), povečanje energetske varnosti, stabilizacija in nato zmanjševanje porabe energije, večja, a naravovarstveno pretehtana raba domačih obnovljivih virov energije, ohranjanje ekosistemskih storitev, pokrajinske in biotske raznovrstnosti ter tudi okoljsko uravnotežen, skladnejši regionalni razvoj celotnega poseljenega ozemlja Slovenije.

Zaradi ugodne geografske in podnebne lege ter praviloma dobro ohranjene narave in privlačne kulturne pokrajine imajo Slovenija in njene regije potencialno izpolnjene vse pogoje, da prebivalci živijo v raznovrstnem in najbolj kakovostnem bivalnem okolju, hkrati pa se na številnih območjih razvija sonaravni turizem. Obstoječe oblike onesnaženosti okolja zlasti v urbanih ekosistemih niso nepovratne, kakovost zraka in vodnih virov je mogoče bistveno izboljšati, več prizadevanj pa bo treba vložiti tudi v finančno zahtevno rekultivacijo zemljišč, ki so zastrupljena s težkimi kovinami (Mežiška dolina, okolica Celja, Idrije, Jesenic itd.). Glede na stabilizacijo prebivalstva in koncept okoljskega prostora bi morali v Sloveniji v najkrajšem času doseči stabilizacijo pozidanih površin, zelo omejene nujne nove pozidave pa vezati na hkratnost rekultivacije degradiranih in neuporabnih pozidanih površin.

Slovenija lahko, če se odloči za sonaravni in socialni razvojni model z aktiviranjem regionalnih virov, postopno dvigne kakovost materialne blaginje, poveča zaposlenost, izboljša kakovost okolja in ohranja primerne pogoje za prihodnje generacije in druge vrste. Seveda odločitev za spremembo razvojne paradigme in z njim povezanega vrednostnega sistema ni preprosta, ni mogoča brez določenih pretresov, a je po našem mnenju neizogibna. Če bi zdaj sprejeli odločitev za prehod na trajnostno sonaravni razvojni model in materialno zmeren, zmogljivostim okolja prilagojen in socialno ter regionalno pravičnejši družbeni model, bi lahko do sredine 21. st. dosegli bistveno višjo kakovost življenja v okviru planetarne in lokalne zmogljivosti okolja. Slovenija lahko glede na lastne razvojne, zlasti naravne kapitale, doseže vodno, prehransko in energetsko samozadostnost, kar pa ne pomeni, da postane avtarkična država.

Vendar menimo, da je ob potrebnem razvojnem dohitevanju v prihajajočem negotovem svetu na eksistenčno ključnih nacionalnih področjih treba okrepiti ključna materialna področja samozadostnosti (in identiteto!), saj v nasprotju s številnimi državami to lahko izvedemo. Ključni domači strateško pomembni kapitali in zelo ugodna geografska lega ter zmerna gostota poselitve nam namreč omogočajo, da inovativno, bolj samozavestno in pospešeno odločno stopimo na sonaravno tlakovano razvojno pot. $Z$ večjo stopnjo samooskrbe in zmanjšanjem uvoza surovin, hrane in energije lahko med drugim bistveno zmanjšamo ekološki in ogljični odtis in s tem prispevamo večji delež k planetarni okoljski in socialni odgovornosti. Samooskrba s strateško ključnimi dobrinami je tudi sistematični 
stabilizator, ki nam bo pomagal pomembno amortizirati prihodnje asimetrične šoke iz tujine, katerim se zaradi potrebne večplastne odprtosti Slovenija kot majhna država seveda ne bo mogla nikoli popolnoma izogniti. Gospodarska recesija, težave pri oskrbi z nafto in zemeljskim plinom, suša poleti 2003 so dovolj nazorno opozorili na energetsko, prehransko in vodno ranljivost Slovenije ter na nujnost prilagajanja podnebnim spremembam. Samooskrba na ključnih, eksistenčno pomembnih poljih in sonaravna inovativnost sta torej pomembna razvojna in socialna obrambna mehanizma, v negotovi prihodnosti čedalje pomembnejša sestavina širše pojmovane nacionalne varnosti.

Med okoljsko ključnimi izhodišči sta poleg povečanja sonaravne rabe obnovljivih naravnih virov tudi ničelna rast porabe energije (potem pa čimprejšnje zmanjšanje porabe), bistveno zmanjšanje izpustov toplogrednih plinov in občutno zmanjšanje ekološkega odtisa na osebo do leta 2025. Slovenija je sicer leta 2013 podprla stališča večine članic EU o 40-odstotnemu zmanjšanju izpustov toplogrednih plinov do leta 2030 glede na izpuste leta 1990. Vendar bi bilo na podlagi znanstvenih ugotovitev treba po oceni Greenpeacea izpuste do leta 2030 zmanjšati za $55 \%$, delež obnovljivih virov energije pa povečati na $45 \%$. Namesto načrtovanja novih termoelektrarn in drugega bloka jedrske elektrarne bi morali v investicijsko ospredje postaviti podporo gospodarstvu in gospodinjstvom, da bi stabilizirali in čim prej začeli zmanjševati porabo energije! V popolnem nasprotju s strategijo podpore obnovljivim virom energije so pretekli vladni ukrepi o zmanjšanju podpore sončnim elektrarnam in avgusta 2014 sprejeta Uredba o dopolnilnih dejavnostih na kmetiji, ki na seznamu nima proizvodnje električne energije s pomočjo sončne energije.

Bistveno večjo pozornost in podporo države bo zaradi velike porabe energije za ogrevanje treba nameniti celoviti in sistematični energetski prenovi zgradb, po letu 2020 sprejeti zakon o obvezni individualni in javni gradnji zgolj pasivnih zgradb, zgostitvi zlasti urbanega prebivalstva v bližini prog javnega prevoza (avtobus, železnica) ter v mestnih jedrih in preusmerjanju sklenjenih oblik podeželske pozidave na vzpeta prisojna pobočja nad najbolj rodovitnimi ravninami (le $18 \%$ državnega ozemlja) z območji dragocene talne vode.

Gospodarska recesija, težave pri oskrbi z nafto in zemeljskim plinom, pogostejše suše in poplave so dovolj nazorno opozorili na energetsko, prehransko in vodno ranljivost Slovenije ter na nujnost prilagajanja podnebnim spremembam. Samooskrba in sonaravna inovativnost sta torej pomembna razvojna in socialna obrambna mehanizma, v negotovi prihodnosti pa tudi čedalje pomembnejši sestavini nacionalne varnosti. Brez udejanjanja koncepta decentralizacije in s tem povezane nujnosti takojšnje ustanovitve dovolj velikih in avtonomnih pokrajin oziroma razvojnih regij (največ 8-10) ne bo prišlo do aktiviranja regionalnih razvojnih potencialov in s tem povezane večje stopnje samooskrbe in na drugi strani do povečanja konkurenčnosti in samozavestnega tekmovanja na svetovnem trgu. Slovenija je namreč že dosegla zgornjo mejo intenzivnosti dela, njeni ključni razvojni potenciali so znanje (z inovativnostjo), razpoložljivi obnovljivi regionalni naravni in drugi viri ter ugodna geografsko-podnebna lega. Seveda Slovenija in njene regije ne smejo postati avtarkične, samozadostne skupnosti, gospodarsko in kulturološko odprtost v obdobju globalizacije pa je treba uravnovesiti z regionalizacijskimi (decentralizacijskimi) 
mehanizmi krepitve večplastne nacionalne in regionalne identitete, vključno z večjo samooskrbo. Pri načrtovanju razvoja pa je potrebno upoštevati dejstvo, da so trajnostni razvojni potenciali slovenskih regij zelo različni (Vintar Mally, 2009).

Slovenija proizvaja na prebivalca planetarno nesprejemljive količine toplogrednih plinov, zato je seveda nujen tako prehod v nizkoogljično gospodarstvo in način življenja kot prilagajanje podnebnim spremembam v gospodarstvu, bivanju in preživljanju prostega časa. Napovedi intenzivnosti podnebnih sprememb kažejo, da občutljivost Evrope narašča od severa proti jugu, torej bo Južna Evropa (in s tem Slovenija) bolj prizadeta (Kobold, Ulaga, 2010). Vplivale bodo na ekosisteme, narodno gospodarstvo, vodno oskrbo, na zdravje prebivalcev, njihovo blaginjo, pa tudi na povečanje ekološke občutljivosti vodnih virov. Pričakovati je njihov vpliv zlasti na kmetijstvo, biotsko pestrost, vodni krog in obalno linijo (dvig morske gladine), energetiko, turizem in promet. D. Ogrin (2003) opozarja, da se $\mathrm{z}$ višjimi temperaturami napovedujeta submediteranizacija podnebja $\mathrm{V}$ osrednji Sloveniji in večja sušnost. Tudi podnebje severovzhodne Slovenije postaja toplejše in bolj sušno, jeseni pa toplejše in bolj vlažno, kar povečuje sušno ogroženost (D. Ogrin, 2009). Izjemna pokrajinska pestrost Slovenije se kaže tudi v veliki raznolikosti poplav in poplavnih območij (Natek, 2005).

Po mnenju Kajfež Bogatajeve (2012, str. 113) lahko v prihodnjih dvajsetih letih pričakujemo, da se bo povprečna letna temperatura v Sloveniji zvišala za $1{ }^{\circ} \mathrm{C}$. Tudi za geografsko in podnebno zelo prehodno Slovenijo pa so najbolj negotove napovedi o količini padavin. V primeru nekoliko večje količine letnih padavin (za $10 \%$ ) bo po mnenju Kajfež Bogatajeve (2012) tudi ob predvidenih višjih temperaturah v večjih slovenskih porečjih dovolj vodnih virov, bistveno zmanjšanje količine padavin in s tem povezano zmanjšanje odtokov (tudi zaradi večjega izhlapevanja) pa bi v številnih porečjih zlasti vzhodne Slovenije povzročilo bistveno povečanje sušnih območij, ki naj bi se razširila tudi v osrednji del Slovenije. Če se bo letna količina padavin zmanjšala zgolj za $10 \%$, povprečna temperatura pa dvignila za $1{ }^{\circ} \mathrm{C}$, se bo odtok vode npr. v že sušnem Pomurju (letna količina padavin je okoli $800 \mathrm{~mm}$ ) zmanjšal za skoraj 70 \%, v namočenem Posočju (letna količina padavin je okoli $2500 \mathrm{~mm}$ ) pa 'le' za $17 \%$.

Strokovnjaki menijo, da bodo v Sloveniji nekatere pričakovane pozitivne posledice podnebnih sprememb (npr. gnojilni učinek s povečano fotosintezo rastlin, daljša vegetacijska doba, zvišanje zgornje meje uspevanja nekaterih poljščin, povečana količina sončnega obsevanja in s tem povezane manjše energetske potrebe za ogrevanje pozimi) bistveno manjše od negativnih (povečanje sušnosti in nevarnosti poplav, pogostejši gozdni požari, toča, neurja in pozebe, otežena oskrba z vodo, večja ranljivost vodnih virov, povečanje potreb po klimatskih napravah v vročih poletjih), kar bo okrepilo pomen sonaravnega regionalnega načrtovanja pokrajinske rabe zlasti v bolj občutljivih pokrajinskoekoloških tipih s pričakovanimi večjimi podnebnimi spremembami.

Od vseh pričakovanih vplivov podnebnih sprememb bodo v Sloveniji verjetno ekstremni vremenski dogodki (poplave, suše, neurja) najbolj negativno vplivali na blaginjo v prihodnjih desetletjih, saj so glede na škodo v zadnjih desetletjih že močno prisotni.

Strategija prilagajanja slovenskega kmetijstva in gozdarstva med drugim poudarja naslednje ključne ukrepe prilagajanja (Kajfež Bogataj in sod., 2008): 
- uvrstitev gradnje zadrževalnikov vode in namakalnih sistemov med najpomembnejše cilje kmetijske politike (tudi zagotavljanje večje prehranske varnosti);

- trajnostno zagotavljanje ekonomske varnosti kmetij ob ekstremnih vremenskih razmerah - prek zavarovalnic in sofinanciranja premij;

- zagotavljanje možnosti za izvajanje dopolnilnih dejavnosti, ki zmanjšujejo ranljivost kmetij ob ekstremnih vremenskih razmerah;

- sprememba namembnosti zemljišč zaradi ponavljajočih se suš (tudi zaradi poplav ali plazenja zemljišč).

Ranljivost regij (NUTS 2) EU glede podnebnih sprememb kaže na velike medregionalne razlike, najbolj ranljive pa so po strokovni oceni obalne, gorske, gosto naseljene urbane regije in regije, ki so izpostavljene rečnim poplavam (Climate change, impacts ..., 2012, str. 216). Mestna regija Ljubljane je bila glede na pričakovane podnebne spremembe uvrščena med poplavno najbolj ogrožene urbane evropske regije s potencialno velikimi družbenimi in ekonomskimi vplivi. Večina regij Slovenije je bila glede na skupni potencialni vpliv podnebnih sprememb (26 kazalcev) uvrščena v četrti, drugi najbolj ogroženi tip, Osrednja Slovenija, Zasavje in Spodnje Posavje pa v potencialno podnebno najbolj ogroženi tip s pričakovanimi velikimi negativnimi vplivi. Splošne zmogljivosti slovenskih regij (16 kazalcev) glede prilagajanja podnebnim spremembam so bile ocenjene kot zmerne ali visoke (2. in 3. razred). Po skupni potencialni ranljivosti za podnebne spremembe (rezultanta skupnih negativnih vplivov in splošne zmogljivosti) so bile statistične regije (12) Slovenije uvrščene v naslednje tipe (Climate change, impacts ..., 2012, str. 221):

- visoka ranljivost (najbolj ranljiv tip): Osrednjeslovenska regija;

- zmerna ranljivost: Pomurje, Zasavje, Spodnje Posavje, Savinjska regija, Jugovzhodna Slovenija, Notranjsko-kraška in Obalno-kraška regija;

- nižja ranljivost: Gorenjska, Goriška, Podravska in Koroška regija.

Lahko povzamemo, da se nekatere slovenske pokrajine kljub geografski legi v zmernih širinah in z bogatimi vodnimi viri uvrščajo med zmerno do visoko podnebno ranljive evropske regije. Zato so še toliko bolj nujne skupna nacionalna strategija in sektorske ter regionalne strategije prilagajanja podnebnim spremembam, delno zasnovane tudi na zgodovinskih izkušnjah.

Slovenija bi morala ob upoštevanju geografskih in drugih svojstvenih potez začeti potrpežljivo in dolgoročno dograjevati temelje trajnostnega prehoda, najprej na občutljivem in okoljsko-podnebno ključnem energetskem in prometnem področju ter v kmetijstvu, postopoma pa tudi na širšem področju eksistenčne nevzdržnosti sedanjega modela trajne gospodarske rasti. Do leta 2050 bo morala Slovenija dejansko biti brezogljična družba, izpuste toplogrednih plinov bo treba zmanjšati za najmanj 80 (90) \% glede na leto 1990, vsaj za $20-30 \%$ do leta 2020 in za najmanj $40 \%$ do leta 2030.

Slovenija je kot večplastno odprta država vpeta $\mathrm{v}$ evropski in svetovni sistem, kar omejuje možnosti za hitro in izolirano uveljavljanje razvojnega koncepta brez gospodarske rasti. Tudi sicer bi bila za tako radikalno spremembo potrebna široko družbeno 
soglasje in pripravljenost prebivalcev na velike spremembe, saj smo v krizi, povzročeni z napredujočo razvojno entropijo in tehnološkim zaostajanjem. Obenem po mnenju Vendraminove (2011) in Drenovca (2013a; 2013b) Sloveniji manjka še precej podjetniškega in tehnološkega znanja, da bi lahko imeli uspešno gospodarstvo, ki bi bilo tehnološko bolj razvito, manj energetsko intenzivno in potratno. Slovensko gospodarstvo po mnenju ekonomista Drenovca (2013b, str. 126) še vedno temelji na slabo plačanem srednje kvalificiranem delu. Energija in talenti, razmišljanje in vrednotenje se morajo usmeriti od asfalta, železa in betona. Recepti za razvojno obnavljanje 'dobrih' starih časov so samo recepti za izgubljanje trajnostnega razvojnega preboja, potrebujemo pa nove razvojne priložnosti, sonaravno in podnebnim spremembam prilagojeno rabo številnih endogenih, regionalnih razvojnih kapitalov.

Učinkovita uporaba okoljskih virov je v tem pogledu čedalje manj zgolj okoljski izziv in (ob podpori izvoznih paradnih konjev) vse bolj temeljni pogoj za doseganje konkurenčnosti podjetij, tehnologij, gospodarstev in blaginje prebivalcev. Potrebujemo razvoj, ki bo temeljil na manjši porabi virov pri proizvodnji, zmanjšani porabi primarnega blaga ter na ustvarjanju poslovnih priložnosti in delovnih mest v dejavnostih, ki bodo omogočale doseganje zastavljenih ciljev. Slovenija bi morala zmanjšati obdavčitev dela in to nadomestiti z višjimi dajatvami za onesnaževanje in uporabo virov ter zagotoviti sveže pobude, s katerimi bo porabnike prepričala, naj se odločajo za izdelke, ki so gospodarni z viri. Le tako lahko prekinemo povezavo med gospodarsko rastjo in rabo primarnih virov ter preidemo v družbo, gospodarno z naravnimi viri (Plan B za Slovenijo ..., 2012).

Zelena javna naročila in zelene investicije države, ozelenjena davčna politika (zmanjševanje obremenitev dela in povečevanje okoljskih davčnih obremenitev, večja obremenitev najbogatejših in kapitala), opustitev okoljsko spornih subvencij, trajnostna vzgoja in izobraževanje, vsem dostopno zdravstvo, sistematično spodbujanje odpiranja ozelenjenih in zdravju neškodljivih delovnih mest so pomembni državni instrumenti za podporo trajnostnemu gospodarskemu razvoju in ohranjanju izjemnega okoljskega kapitala naše države in vseh njenih regij. Zgolj okolju škodljive subvencije v transportu, energetiki in kmetijstvu v Sloveniji so v letu 2011 znašale 500 mio. evrov (Sonnenschein, 2013). Postopna odprava teh subvencij bi pripomogla k uravnoteženju javnih financ in izboljšala konkurenčnost podjetij z nizkim okoljskim odtisom. Okoljski davki do zdaj pri reševanju problema energetske intenzivnosti slovenskega gospodarstva (ta je nad evropskim povprečjem) še niso bili dovolj učinkoviti. Priložnost za dodaten davčni prihodek in izboljšanje energetske učinkovitosti je npr. zvišanje davka na $\mathrm{CO}_{2}$ in trošarin. Pri tem pa je treba upoštevati tudi problem energetske revščine, ki v Sloveniji narašča. Priložnosti za podporo zelenemu razvojnemu preboju so tudi na strani izdatkov. Če bodo investicije usmerjene na področja sedmih programov zelenega razvojnega preboja in bodo imele 'zelene' teme prednost pri programiranju evropskih skladov v prihodnji finančni perspektivi EU, ne bodo potrebna dodatna finančna sredstva.

Glede na okoljske pritiske in okoljska bremena so v Sloveniji ključna vsebinska področja zelene, nizkoogljične prenove gospodarstva (razen integracije čistih tehnologij in strategij upravljanja): 
- sonaravna rekonstrukcija ključnih področij sodobnih ekonomij: energije (energetike), prometa, gradbeništva, kmetijstva in industrijske proizvodnje osnovnih materialov (železo, aluminij, cement in papir), ki porabijo veliko energije in močno obremenjujejo okolje;

- gradnja zelene javne infrastrukture: pametno omrežje električne energije iz obnovljivih virov, modernizacija tirnega prometa, razvoj in raba okolju prijaznejših vozil, modernizacija javnega prometa, reciklaža materialov;

- premik digitalne v zeleno revolucijo: vključitev informacijskih tehnologij za dematerializacijo naše ekonomije in ustvarjanje novih delovnih mest;

- ustvarjanje več zelenih delovnih mest: zelena ekonomija kot gonilna sila novih delovnih mest pri gradnji nizkoogljičnega, sonaravnega svetovnega gospodarstva.

Glede na obstoječe znanje, gospodarsko strukturo in izkušnje ima Slovenija največje možnosti pri naslednjih nizkoogljičnih tehnologijah oziroma verigah dodane vrednosti (Zakon o podnebnih spremembah ..., 2010):

- energetika stavb in geotermija (energetska učinkovitost in energetska sanacija zgradb, globinska in plitva geotermalna energija);

- pametna omrežja in fotovoltaika (pametna energetska omrežja - električna in toplovodna omrežja, ki omogočajo učinkovito vključevanje obnovljivih virov energije, krmiljenje porabe; sončne celice za proizvodnjo električne energije);

- javni prevoz: kratkoročno avtobus, srednjeročno železnica;

- električni avtomobil in njegove komponente: polnilna mesta, elektromotorji, baterije, krmiljenje;

- trajnostno gospodarjenje z gozdovi, les kot gradbeni material, lesni izdelki in raba lesnih ostankov za proizvodnjo energije;

- ekološko kmetijstvo.

Samooskrba s strateško ključnimi dobrinami je tudi sistematični stabilizator, ki nam bo pomagal pomembno amortizirati prihodnje asimetrične šoke iz tujine, katerim se zaradi potrebne večplastne odprtosti Slovenija kot majhna država seveda ne bo mogla nikoli popolnoma izogniti. Domači okoljski viri in zelo ugodna geografska lega ter zmerna gostota poselitve nam namreč omogočajo, da inovativno, bolj samozavestno in pospešeno odločno stopimo na sonaravno tlakovano razvojno pot. Ob varčni in stabilni, sonaravni rabi nam domači okoljski viri omogočajo trajno in zanesljivo samooskrbo z vodo, obnovljivimi viri energije, lesom, ugodno bivalno okolje, sonaravni razvoj turizma in rekreacije ter opravljanje ključnih ekosistemskih funkcij.

$\mathrm{Na}$ državni ravni razpolaga Slovenija $\mathrm{z}$ bogatimi vodnimi viri, ki bodo tudi v morebitnih zaostrenih podnebnih razmerah omogočali zanesljivo vodno oskrbo. Vendar nas sušno leto 2003 opozarja, da se lahko hidrološka in kmetijska suša pojavi na več kot polovici ozemlja Slovenije. Potrebna bosta varčna poraba vode in zmanjševanje obremenjevanja vodnih virov, zlasti tekočih voda in območij talne vode (kmetijstvo, urbanizacija). Slovenija in njene regije razpolagajo z mavrico decentraliziranih obnovljivih virov energije, ki ob potrebnem zmanjšanju porabe primarne in končne energije omogočajo 
doseganje popolne energetske samooskrbe do sredine 21. st. Ob hidroenergiji naj bi do leta 2050 sončna in geotermalna energija (toplota in soproizvodnja električne energije) postali steber trajnostne energetike Slovenije. Energetska raba lesa naj bi bila podrejena njegovi surovinski rabi, vendar velike lesne zaloge in prirasti omogočajo tudi pomembnejšo vlogo lesa v energetskih bilancah zlasti bolj gozdnatih regij Slovenije (individualno in daljinsko ogrevanje, soproizvodnja toplote in električne energije). Vetrna energija bo zaradi prevladujoče zavetrne lege Slovenije imela manjšo, omejeno vlogo.

Po večini ocen teoretičnega in gospodarsko izkoristljivega potenciala OVE sta dolgoročno ključna domača vira ob hidroenergiji še sončna in geotermalna energija. Med nacionalno prednostnimi sonaravnimi samooskrbnimi področji pa bosta po našem mnenju ponovno doseganje varne stopnje prehranske samooskrbe ter pridelava domače kakovostne in zdrave hrane po vsej verjetnosti najzahtevnejši strateško trajnostni razvojni nalogi na državni ravni. Zlasti zaradi skromne stopnje prehranske samooskrbe Slovenije kmetijska zemljišča ni primerno uporabljati za proizvodnjo biogoriv, v prihodnje pa bo treba več vode (manjši zadrževalniki) nameniti za namakanje. $Z$ večjo stopnjo samooskrbe in zmanjšanjem uvoza surovin, hrane in energije lahko med drugim bistveno zmanjšamo ekološki in ogljični odtis in s tem prispevamo večji delež k planetarni okoljski in socialni odgovornosti ter razvojnemu preboju.

Trajnostnemu sonaravnemu razvoju v Sloveniji stoji na poti vrsta ovir: slabi pogoji za trajnostno mobilnost (predvsem nefunkcionalnost javnega prometa), kljub nekaterim ukrepom še vedno majhna podpora ekološkemu kmetijstvu in posledično nezadostne količine lokalno ekološko pridelane hrane, netrajnostna gradnja turističnih objektov, energetska neučinkovitost, pomanjkljivi sistemi ravnanja z odpadki, togost zakonodaje in administrativne ovire, marginaliziranje pomena pravičnih odnosov v oskrbovalnih verigah, pomanjkanje kakovostnih, izobraženih in motiviranih kadrov v gostinstvu in turizmu ter splošno nepoznavanje trajnostnih praks (Plan B za Slovenijo ..., 2012).

Tudi zeleni, sonaravni turizem je slovenska neizkoriščena razvojna priložnost. Zeleni turizem ima potencial povezovalca in spodbujevalca decentraliziranega razvoja, spodbujevalca razvoja lokalnih delovnih mest, spodbujevalca uravnoteženega razvoja in kohezije med mestom in podeželjem, dodajanja vrednosti kmetijskim proizvodom, obrti in malemu gospodarstvu ter nosilca ukrepov za prilagajanje podnebnim spremembam.

\section{RAZVOJNO-OKOLJSKI PREBOJ SLOVENIJE IN ZELENA DELOVNA MESTA}

Prostorsko, okoljevarstveno, naravovarstveno in medgeneracijsko odgovorna in smotrna raba trajnostnih okoljskih virov Slovenije je razvojna in okoljska nujnost, ki bi hkrati bistveno povečala število zelenih delovnih mest v vseh regijah in tudi različne oblike samooskrbe. Najobsežnejši in najbolj dodelan trajnostni program razvoja Slovenije do leta 2020, ki temelji na rabi domačih naravnih virov, je Plan B za Slovenijo (2012). Nevladne okoljske in sorodne organizacije so novembra 2012 Vladi RS poslale poziv, naj novo Strategijo razvoja Slovenije za obdobje 2014-2020 žariščno usmeri v zeleni 
razvojni preboj in s tem Sloveniji omogoči optimalno rabo domačih potencialov. Slovenija bo imela v obdobju 2014-2020 možnost pridobiti več milijard evrov namenskih razvojnih sredstev iz evropskih skladov. To bodo v prihodnjih letih verjetno naša osnovna razpoložljiva sveža razvojna sredstva, kako jih bomo porabili, pa bo določila nova Strategija razvoja Slovenije. Strategija naj vključuje vitalne programe na sedmih družbeno pomembnih področjih (Plan B za Slovenijo ..., 2012; Ogorelec, Karba, 2013): (1) prehranska samooskrba, (2) vrednostna veriga lesa, (3) energetska prenova stavb, (4) prehod na obnovljive vire energije, (5) posodobitev železniškega omrežja in javnega prevoza, (6) učinkovita raba naravnih virov in (7) zeleni turizem.

Programi zelenega razvojnega preboja so usmerjeni v rešitve in omogočajo dolgoročni izhod iz krize. Odzivajo se na strateške priložnosti ter izhajajo iz domačih človeških in naravnih virov. Zmanjšujejo odvisnost od uvožene hrane in nafte. Prinašajo regionalno uravnotežen razvojni zagon v mesta in na podeželje. Podpirajo doseganje mednarodno sprejetih podnebnih ciljev. Ustvarjajo nova delovna mesta z višjo dodano vrednostjo in spodbujajo inovativne rešitve. Podajajo pozitivno vizijo in imajo velik potencial za doseganje visoke stopnje družbenega soglasja.

Glede na lastne naravne vire naj bi bilo po našem mnenju jedro slovenskega inovacijskega, trajnostnega razvojno-okoljskega preboja z okoli 50.000-60.000 novimi ozelenjenimi delovnimi mesti naslednje (Plut, 2014):

- predelava lesa: 20.000-30.000 (do leta 2020 po oceni direktorja podjetja Jelovica vsaj 10.000 novih delovnih mest);

- stabilizacija in čimprejšnje povečanje kmetijskih zemljišč, dvig splošne prehranske samooskrbe s 50-60 \% na 80\% in večja vloga delovno intenzivnega sonaravnega, zlasti ekološkega kmetijstva: najmanj 20.000 novih delovnih mest;

- sistematična energetska prenova javnih in zasebnih zgradb: 7000-10.000 novih delovnih mest;

- učinkovita raba energije in večja raba obnovljivih virov energije: najmanj 5000 novih delovnih mest itd.

Tako npr. trajnostno pridobivanje, predelava in raba domačega lesa (prednostna surovinska raba) optimalno povezuje okoljske, podnebne, ekonomske, regionalne, zaposlitvene cilje in povečuje število delovnih mest na podeželju (Pohleven, 2010; Habjanič, 2013; Ogorelec, Karba, 2013). Slovenija bi lahko zlasti na celotni gozdno-predelovalni verigi gradila podobo 'zelene doline' in bila zgled, kako je možno z nacionalnim bogastvom večplastno dobro trajnostno gospodariti. V obdobju 2010-2020 bi lahko količino doma predelane hlodovine povečali za $70 \%$, oziroma od $1.125 .000 \mathrm{~m}^{3}$ lesa na $2.100 .000 \mathrm{~m}^{3}$ (Humar, Kutnar, Piškur, 2013).

Dvig stopnje prehranske samooskrbe (s poudarkom na ekološki pridelavi) je ključnega pomena za zagotavljanje dolgoročne oskrbe z varno, kakovostno in zdravo hrano po dostopnih cenah. Domača pridelava pokriva komaj $20 \%$ potreb slovenskega trga po ekoživilih, 80 \% pa jih uvozimo (Ogorelec, Karba, 2013). Ekološka pridelava hrane je pomembna priložnost za nova delovna mesta, revitalizacijo kmetijstva in podeželja ter dvig kakovosti življenja. 
Stanič (2013) predlaga obdavčitev vseh energentov, zlasti fosilnih. Najbolj naj se obremenijo stanovanjski, energetsko potratni objekti. Stanovalci bodo reagirali z množično dejavnostjo energetske sanacije, sončnimi kolektorji (in fotovoltaiko - opomba avtorja) in tudi z ozelenitvijo zgradb. V tej dejavnosti se odpira okoli 20.000 do 30.000 delovnih mest (Stanič, 2013). Nadalje predlaga, da se naj uveljavi ustavna pravica do vrta kot dolgoročna ekološko-socialna rekreativna človekova pravica.

Energetska prenova stavb je za Slovenijo največja priložnost za povečanje učinkovitosti rabe energije (Ogorelec, Karba, 2013). Habjanič (2013) opozarja, da v Sloveniji obstaja obsežen fond neobnovljenih in energijsko neučinkovitih stavb, saj je bil obnovljen le relativno majhen delež javnih in zasebnih stavb. Tako se je do leta 2013 na Eko sklad obrnilo le $7 \%$ slovenskih gospodinjstev, po strokovnih ocenah pa bi morali do leta 2020 obnoviti več kot $80 \%$ stanovanjskega fonda. Pričakovani prihranki pri toplotni energiji bi bili 50-90 \%, bistveno bi se zmanjšale tudi emisije $\mathrm{CO}_{2}$. V primeru uspešnega zagona in realizacije celovite energijske prenove ter hkratnih vzdrževalnih del na celotnem stanovanjskem stavbnem fondu v Sloveniji bi na področju celovite energijske prenove odprli do 13.400 delovnih mest, na področju investicijsko-vzdrževalnih del pa do 20.160 delovnih mest (Habjanič, 2013, str. 85).

Domači regionalni naravni viri, še vedno dokaj ohranjen socialni kapital (socialna povezanost, še prisotna solidarnost) in izobraženi prebivalci so ključni stebri trajnostnega razvoja Slovenije in vseh njenih pokrajin. Skladnejši regionalni razvoj, decentralizacija in izjemen potencial za varno stopnjo samooskrbe s strateško ključnimi dobrinami (hrana, voda, les in regionalne mavrice obnovljivih virov energije, bogate ekosistemske storitve in biotska raznovrstnost) pa so podporni stebri trajnostnega gospodarskega razvoja in s tem povezane nacionalne varnosti. $Z$ večjo stopnjo samooskrbe in manjšim uvozom surovin, hrane in energije med drugim bistveno zmanjšamo ekološki in ogljični odtis in s tem prispevamo večji delež k planetarni okoljski in socialni odgovornosti Slovenije ter potrebnemu razvojnemu preboju in polni zaposlenosti. Skrajno skrb zbujajoče je dejstvo, da kmetijska dejavnost še naprej upada; tako npr. v letu 2010 pristojna ministrstva niso uspešno zavarovala kmetijskih zemljišč kot pogoja za samooskrbo, kar pa je veljalo tudi za leti 2011 in 2012.

Ohranjanje vodne samozadostnosti in vode kot javnega dobra, zeleni razvojni preboj, povečanje prehranske in energetske samozadostnosti Slovenije mora biti skupaj z ekologizacijo gospodarstva (zlasti energetike in industrije) ena od strateško prioritetnih nalog Slovenije. Slovenija se uvršča v elitno peščico držav sveta (med dvajseterico od dvestotih držav!), ki zaradi geografske lege in mozaične pokrajinske sestave razpolaga s pisano mavrico ključnih naravnih virov na prebivalca (vodni viri, lesna biomasa, regionalni obnovljivi viri energije, kmetijska zemljišča, turistični naravni in kulturni potenciali, ekosistemske storitve), izobraženim prebivalstvom in trajnostnim socialnim, kulturnim kapitalom (še prisotna volja za sodelovanje, zgodovinsko pridobljeno razumevanje solidarnosti, skupnosti in pomena skupnega dobra, razvita lokalna in regionalno pripadnost). Imamo vse možnosti, da postanemo ena od vodilnih in najbolj uspešnih trajnostnih, ekosocialnih (ekosocialističnih) držav, ki lahko do leta 2020 odpre najmanj 50.000-60.000 novih zelenih delovnih mest ter hkrati bistveno zmanjša planetarno in dolgoročno nesprejemljiv obseg izčrpavanja okolja. 
Hribar Milič iz Gospodarske zbornice Slovenije (2014a) ugotavlja, da bi lahko ob primernih sistemskih ukrepih v nekaj letih zagotovili 60.000 delovnih mest, dvignili plače in zagotovili stabilno socialno državo. Nova delovna mesta so: $10.000 \mathrm{v}$ turizmu (npr. z okrepljeno promocijo turizma), $10.000 \mathrm{v}$ lesnopredelovalni industriji (z drugačnimi zakonodajnimi in izvedbenimi okvirji), $15.000 \mathrm{~s}$ povečanjem izvoza industrijskih izdelkov (v letu 2013 je bil ta izvoz dvakrat večji kot leta 2000) in prav toliko na področju infrastrukture. Za doseganje navedenih ciljev predlaga klasične neoliberalne ukrepe, od prodaje državnih podjetij do večje odprtosti za tuje investicije, znižanja davkov gospodarstvu, zmanjšanja prenormiranosti poslovnega okolja, deregulacije trga dela itd. Tako npr. ohranjanje obsega javnega sektorja z zadolževanjem ocenjuje 'kot strel v koleno'. Po njegovem mnenju dvigovanje izdatkov za izobraževanje ne dviguje konkurenčnosti iskalcev zaposlitve, če ti ne bodo pridobili podjetniških kompetenc in ambicioznosti (Hribar Milič, 2014a).

Dodatna, sistemsko zasnovana študija Gospodarske zbornice Slovenije (vključitev številnih podjetij v pripravo raziskave) je prišla do zaključka, da je možno do leta 2020 ustvariti 118.000 novih delovnih mest, od tega 45.000 trajnih in 73.000 vezanih na konkretne investicijske ukrepe (Hribar Milič, 2014b). Med ovirami izpostavlja odsotnost nacionalnega soglasja o investicijskih prioritetah, slabo pripravljenost modelov financiranja in birokratske postopke za umeščanje v prostor. Zgolj s povečanjem izvoza za približno 7 \% je uresničljivih 20.000 novih delovnih mest, s sistematično energetsko prenovo stavbnega fonda bi lahko odprli 13.000 dodatnih delovnih mest. Številna delovna mesta so po ocenah Gospodarske zbornice Slovenije tudi v turizmu, energetiki, informacijski tehnologiji, komunalni infrastrukturi, lesni predelavi, zeleni energiji in malem gospodarstvu (Hribar Milič, 2014b). Priložnosti je po njihovih ocenah veliko, vendar opozarjajo tudi na proces ukinjanja delovnih mest in nujnost sistemskega reševanja precejšnjega dela obstoječega gospodarstva.

Nevladna okoljska organizacija Umanotera je skupaj z zunanjimi sodelavci kljub metodološkim težavam izdelala zaokroženo oceno potenciala zelenih delovnih mest na izbranih prednostnih področjih (Karba in sod., 2014):

- ekološko kmetijstvo: 87.000 delovnih mest ob popolni preusmeritvi vseh 74.500 kmetij v ekološko pridelavo in povečanju kmetijskih površin;

- gozdno-lesne predelovalne verige: 50.000 delovnih mest ob predpostavki, da vsakih $100 \mathrm{~m}^{3}$ predelanega lesa predstavlja eno novo delovno mesto, in preusmeritvi od izvoza hlodovine v predelavo lesa v izdelke $\mathrm{z}$ višjo dodano vrednostjo;

- ravnanje z odpadki: do 5000 delovnih mest ob zmanjšanju odlaganja odpadkov za vsaj $40 \%$ in povečani ponovni uporabi in reciklaži;

- raba obnovljivih virov energije za izgradnjo, instalacije, obratovanje in vzdrževanje (električna energija in ogrevanje ter hlajenje): do 11.400 delovnih mest ob naložbah v višini nad 560 mio. evrov (2010-2020) in povečanju zmogljivosti (decentralizirane) proizvodnje OVE;

- učinkovita raba energije, energetska sanacija zgradb: povečanje energetske učinkovitosti stavb v javni in zasebni lasti, 1000 delovnih mest ob $1 \%$-nem znižanju porabe energije in do 13.500 delovnih mest ob prenovi celotnega stavbnega fonda $v$ desetih letih;

- trajnostni turizem: nad 100.000 delovnih mest ob predpostavki ozelenitve celotnega turizma, temelječega na lokalnih virih in na sonaravnem razvoju turistične infrastrukture. 
V celoti je skupni potencial Slovenije po študiji Umanotere za skoraj 250.000 zelenih delovnih mest do leta 2020 (Karba in sod., 2014, str. 5). Na presečnem področju socialnega podjetništva pa je bil potencial ocenjen na 80.000 delovnih mest. Konec leta 2013 je bilo število delovnih mest v sektorju okoljskega blaga in storitev za leto 2011 ocenjeno na nekaj več kot 30.000 , oziroma 3,2\% vseh zaposlenih, ki so ustvarili $9 \%$ celotnega izvoza oziroma 11,6 \% BDP. Zelena delovna mesta so torej imela poudarjen izvozni pomen in bistveno nadpovprečno dodano vrednost (skoraj štirikrat višjo od povprečja na zaposlenega). V socialnem podjetništvu pa je leta 2010 bilo 20.000 delovnih mest (Karba in sod., 2014, str. 4-5).

V Sloveniji je torej potencial za zelena delovna mesta izjemno velik, trajnostno konkurenčnost bi ob ustreznemu načrtovanju in upravljanju države lahko gradili zlasti na lokalnih naravnih in človeških virih. Podčrtati pa velja, da prikazani zaposlitveni zeleni potenciali niso enaki kot projekcije zaposlovanja, saj gre pri potencialih za teoretične zgornje meje števila delovnih mest. Uresničevanje potenciala zelenih delovnih mest je pomembno zaradi zmanjševanja škodljivih vplivov na okolje, povečanja konkurenčnosti in zmanjšanja perečega problema brezposelnosti. Zeleni turizem lahko postane nosilec decentraliziranega razvoja naše države, njegov naravni in kulturni potencial za ustvarjanje kakovostnih lokalnih delovnih mest je obsežen (Ogorelec, Karba, 2013). Zelena delovna mesta lahko ustvarjajo tudi razvojno naravnani trajnostni projekti, ki hkrati zmanjšujejo prekomerne urbane okoljske odtise in povečujejo samooskrbo (urbani vrtovi, pridelava hrane na strehah, terasah, balkonih, nakupi hrane pri bližnjih kmetih itd.). Delovna mesta v zelenem gospodarstvu lahko ključno prispevajo k dvigu zaposlenosti v starostni skupini 20-64 let od $67 \%$ na $75 \%$ do leta 2020 . Potrebno pa bo dobro načrtovanje in trajnostno izobraževanje, namenski politični ukrepi države in občin, podpora sindikatov in znanosti, trajnostno usmerjena poraba evropskih sredstev, ambiciozna podjetja, kmetije in posamezniki.

Ključni trajnostni ustvarjalni moči Slovenije sta izjemen okoljski trajnostni kapital (domači obnovljivi naravni viri) in znanje. Izobraženo in samozavestno prebivalstvo, ustvarjalni naboj zlasti izobražene mlajše generacije, inovacijsko moč znanosti, umetnosti in kulture je treba usmeriti v dvig kakovosti in radosti življenja za vse, v dvig kakovosti gospodarstva kot materialne osnove (vključno s trajnostno usmerjeno industrijo), ohranjanje javnega dobra in vsem dostopnih, kakovostnih javnih storitev. Prioritetne razvojne investicije Slovenije morajo torej postati zlasti vlaganja $\mathrm{v}$ večjo, trajnostno regionalno rabo domačih naravnih virov (nova zelena delovna mesta $\mathrm{v}$ vseh regijah), $\mathrm{v}$ ekologizacijo gospodarstva in ohranjanje kakovosti javnih storitev ter vlaganja v trajnostno znanje ter zaposlitev mladih. Po mnenju Murnove (2013) so pomembna potencialna delovna mesta še na področju oskrbe čedalje večje populacije ostarelega prebivalstva, $v$ t. i. storitveni industriji, predvsem v strokovnih, znanstvenih, tehničnih in informacijsko-komunikacijskih dejavnostih.

Trajnostni sonaravni razvojni model ravnovesnega, količinsko (snovno-energetsko) nerastočega, snovno krožnega gospodarstva in načina življenja je Sloveniji, njenim naravnim, poselitvenim in regionalnim značilnostim dobesedno pisan na 'geografsko' kožo. Zasnove policentričnega razvoja je treba okrepiti, Slovenija se je na srečo izognila (pre) obsežni metropolizaciji Ljubljanske kotline, vendar v zadnjem obdobju prihaja zgolj do 
gravitacijske krepitve manjšega števila večjih mest (zlasti Ljubljane) in ponovnega povečevanja razlik med regijami. Obstoječi poselitveni vzorec je v veliki meri postal trajnostna prednost Slovenije, saj v primeru odločitve za trajnostno sonaravni razvojni model (namesto neoliberalnega) omogoča kakovostno bivanje, večplastno rabo regionalnih virov in lokalno prilagajanje zmogljivostim okolja. Obenem poseljenost vzpetega sveta omogoča ohranjanje kulturne pokrajine, lažje prilagajanje lokalni zmogljivosti okolja, doseganje varne stopnje prehranske samooskrbe in ohranjanje turistične privlačnosti slovenskega podeželja.

\section{SKLEP}

Sodobno, trajnostno sonaravno pojmovanje razvoja enakovredno obravnava ekonomske, družbene in okoljske cilje, večjo vloga namenja prehranski in energetski samooskrbi, hkrati pa upošteva tudi potrebe prihodnjih generacij. Načrtovanje dviga materialnega blagostanja na osnovi dosedanjega modela količinske gospodarske rasti je okoljsko in prostorsko nevzdržno, nujno je uresničevanje sonaravno zasnovane razvojne paradigme, vključno z varno stopnjo prehranske in energetske samooskrbe.

Po porabi naravnih virov in proizvodnji emisij na prebivalca v Sloveniji (podobno kot $\mathrm{v}$ drugih gospodarsko razvitih evropskih državah) za dva- do štirikrat presegamo planetarno trajno sprejemljivo raven, ekološki odtis na prebivalca je skoraj dvakrat večji od biološke zmogljivosti Slovenije. Tudi zaradi kriznih razmer, visoke stopnje brezposelnosti, izčrpanosti dosedanjega razvojnega modela in medgeneracijskih moralnih ter okoljskih obveznosti potrebuje Slovenija bistveno spremenjeno razvojno paradigmo, korenit družbeno-okoljski preokret.

Večplastna kriza opozarja na strukturno neučinkovitost dosedanjega razvojnega modela in tehnološko zaostajanje gospodarstva, zato so za trajnostni gospodarski in regionalni razvoj ter dvig samooskrbe (na državni in regijski ravni) po našem mnenju potrebni in primerni gospodarski, okoljski ter socialni odgovori. Dolgoročni izhod iz krize torej ni nadaljevanje neoliberalnega razvojnega koncepta, temveč izoblikovanje in udejanjanje trajnostnega sonaravnega razvojnega koncepta Slovenije in vseh njenih regij, ki bo zasledoval blaginjo prebivalcev sedanjih in bodočih generacij in pri tem uravnotežil gospodarski, socialni in okoljski razvoj (Murn, 2013; Plut, 2014). Nemudoma bi morali vzpostaviti nacionalni projekt usposabljanja za zelena delovna mesta. Slovenija torej razpolaga s trajnostnimi okoljskimi viri (vodni viri, gozdni ekosistemi, različni obnovljivi viri energije, potencialna kmetijska zemljišča), ki lahko bistveno povečajo samooskrbo. Sodobna trajnostno, sonaravno zasnovana strategija razvoja mora vključevati tudi varno stopnjo vodne, prehranske in energetske samooskrbe. Seveda Slovenija in njene regije ne smejo postati avtarkične, samozadostne skupnosti, gospodarsko in kulturološko odprtost v obdobju globalizacije pa je potrebno uravnovesiti z regionalizacijskimi (decentralizacijskimi) mehanizmi krepitve večplastne nacionalne in regionalne identitete, vključno z večjo vodno, energetsko in prehransko samooskrbo.

Domači okoljski viri in zelo ugodna geografska lega Slovenije ter zmerna gostota poselitve nam namreč omogočajo, da inovativno, bolj samozavestno in pospešeno odločno 
stopimo na sonaravno tlakovano razvojno pot. Ob varčni in stabilni, sonaravni rabi omogočajo domači okoljski viri trajno in zanesljivo samooskrbo z vodo, obnovljivimi viri energije, lesom, ugodno bivalno okolje ter opravljanje ključnih ekosistemskih funkcij. Med nacionalno prednostnimi sonaravnimi samooskrbnimi polji pa bo po našem mnenju ponovno doseganje varne stopnje prehranske samooskrbe, pridelava domače kakovostne in zdrave hrane, po vsej verjetnosti najbolj zahtevna strateška trajnostna razvojna naloga na državni ravni. Zlasti zaradi skromne stopnje prehranske samooskrbe Slovenije kmetijska zemljišča ni primerno uporabljati za proizvodnjo biogoriv, v prihodnje pa bo potrebno več vode (manjši zadrževalniki) nameniti za namakanje. $Z$ večjo stopnjo samooskrbe in zmanjšanjem uvoza surovin, hrane in energije bomo med drugim bistveno zmanjšali ekološki in ogljični odtis in s tem prispevali večji delež k planetarni okoljski in socialni odgovornosti ter razvojnemu preboju.

Okoljske tehnologije in ozelenjeno podjetništvo, okoljsko odgovorna raba domačih okoljskih virov, sonaravno kmetijstvo, turizem, promet (tirni in javni, kolesarjenje) in gradbeništvo (energetske prenove zgradb, pasivna gradnja, domači gradbeni materiali) ter ekologizirane druge dejavnosti naj ob izvozno naravnani slovenski industriji (potencial za okoli 20.000 novih delovnih mest) postanejo jedro slovenskega inovacijskega, trajnostnega razvojno-okoljskega preboja, ki regionalno razpršeno, decentralizirano odpirajo najmanj 60.000 novih ozelenjenih delovnih mest: večja predelava lesa, 20 \%-no povečanje prehranske varnosti, regionalna raba obnovljivih virov energije, sonaravni turizem in energetska prenova zgradb. Težko je napovedati, kako velik del skupnega slovenskega potenciala zelenih delovnih mest (okoli 250.000; v letu 2013 jih je bilo 30.000) se bo uresničil v prihodnjih desetletjih. Potrebni bodo veliki napori vseh vpletenih deležnikov (zasebna in javna podjetja, kmetije, spodbuden pravni in fiskalni okvir, razvoj sonaravno zasnovanega trga, primerna znanja in spretnosti, večja okoljska ozaveščenost itd.) in močna politična podpora na evropski, državni in lokalni ravni.

Če se bo Slovenija odločila za trajnostno sonaravno vizijo razvoja, bo lahko bogate in regionalno mavrične sonaravne naravne potenciale in znanje mlade generacije odgovorno in učinkovito uporabila za dvig nizkoogljičnega in sonaravnega gospodarstva, povečanje zaposlenosti in samooskrbe, skladnejši sonaravni regionalni razvoj, prilagajanje na podnebne spremembe in hkratno zmanjšanje pritiskov na okolje.

\section{Viri in literatura}

Baker, S., 2006. Sustainable development. London, New York, Routledge, 245 str.

Bat, M., Uhan, J., 2003. Uvod. V: Uhan, J., Bat, M. (ur.). Vodno bogastvo Slovenije. Ljubljana, Agencija RS za okolje, str. 9-12.

Brown, L. R., 2005. Outgrowing the Earth: the food security challenge in an age of falling water tables and rising temperatures. London, Earthscan, 239 str.

Climate change, impacts and vulnerability in Europe 2012: an indicator-based report.

EEE Report 2012/12. Luxembourg, European Environmental Agency, 300 str. URL: http://www.eea.europa.eu/publications/climate-impacts-and-vulnerability-2012. (Citirano 8. 10. 2014). 
Cokan, B., Repe, B., 2013. Vpliv malih hidroelektrarn na populacijo rečne postrvi (Salmo trutta L.) na primeru reke Mislinje. Dela, 40, str. 7-24. DOI: 10.4312/dela.40.1.7-24

Confronting the crisis: austerity or solidarity. European economists for an alternative economic policy in Europe. 2011. Brussels, EuroMemorandum, 56 str. URL: http:// www2.euromemorandum.eu/uploads/euromemorandum_2010_2011.pdf (Citirano 8. 10. 2014).

Daily, G., Kareiva, P., Polasky, S., Ricketts, T. H., Tallis, H., 2011. Mainstreaming natural capital into decisions. V: Kareiva, P., Tallis, H., Ricketts, T. H., Daily, G., Polasky, S. (ur.). Natural capital. Oxford, Oxford University Press, str. 3-14. DOI:10.1093/ acprof:oso/9780199588992.003.0001

Declaration on green growth. 2009. New York, OECD, 2 str. URL: http:/www.oecd.org/ env/44077822.pdf (Citirano 3.11. 2014).

Drenovec, F., 2013a. Kolaps elite: iskanje normalnosti in prednosti v majhni evropski državi. Ljubljana, Založba /*cf., 234 str.

Drenovec, F., 2013b. Opozorilo. V: Šoštarič, N. (ur.). Kam plovemo? Premisleki o izhodu iz krize. Ljubljana, Založba Sanje, str. 125-131.

Earnings, jobs and innovation: the role of recycling in a green economy. 2011. EEA Report, 8/2011, 26 str. URL: http:/www.eea.europa.eu/publications/earnings-jobs-and-innovation-the (Citirano 2. 10. 2014).

Elliott, D., 2003. Energy, society and environment. London, New York, Routledge, 346 str. Energiemasterplan Kärnten. 2014. Klagenfurt (Celovec), Amt der Kärntner Landesregierung, 124 str. URL: http://www.energie.ktn.gv.at/294680_DE-Dateien-eMAPgesamtweb.pdf (Citirano 14. 10. 2014).

From vision to action. A workshop report on $100 \%$ renewable energies in European regions. 2013. Hamburg World Future Council, Climate Service Center, 39 str. URL: http://www.worldfuturecouncil.org/fileadmin/user_upload/Climate_and_Energy/ From_Vision_to_Action_Policy_Recommendations_for_100_RE_in_European_ Regions.pdf (Citirano 10. 10. 2014).

Green jobs and occupational safety and health. 2013. Luxembourg, European Agency for Safety and Health at Work, 208 str. DOI: 10.2802/39554

Habjanič, S., 2013. Osnutek programa za spodbujanje energijsko učinkovite gradnje in prenove stavbnega sektorja. V: Šoštarič, N. (ur.). Kam plovemo? Premisleki o izhodu iz krize. Ljubljana, Založba Sanje, str. 78-88.

Hanžek, M., Gregorčič, M., Kajfež Bogataj, L., Kreft, L., Murn, A., Plut, D., Stanovnik, T., Školjč, J., Trontelj, J., 2010. Kam po krizi? Prispevek k oblikovanju trajnostne vizije prihodnosti Slovenije. Ljubljana, Kabinet predsednika vlade RS. URL: http:// www.itr.si/uploads/cP/-z/cP-zTe-5MVy1MKZgrGwM0A/kam-po-krizi.pdf (Citirano 13. 10. 2014).

Harou, P., Bellu, L. G., Cistulli, V., 2002. Environmental economics for sustainable growth: a handbook for practitioners. Cheltenham, Edward Elgar Pub, 528 str.

Hribar Milič, S., 2014a. 60.000 novih delovnih mest ni iluzija. Delo, Sobotna priloga (7. 2. 2014). URL: http://www.delo.si/zgodbe/sobotnapriloga/60-000-novih-delovnih-mest-ni-iluzija.html (Citirano 8. 10. 2014). 
Hribar Milič, S., 2014b. Prijetno presenečenje: potencial za nova delovna mesta obstaja. Delo, Sobotna priloga (7. 6. 2014). URL: http://www.delo.si/zgodbe/sobotnapriloga/ prijetno-presenecenje-potencial-za-nova-delovna-mesta-obstaja.html (Citirano 20. 9. 2014).

Hrustel Majcen, M., 2004. Trajnostni razvoj in kmetijstvo. V: Lah, A. (ur.). Sonaravno uravnoteženi razvoj Slovenije (zbirka Usklajeno in sonaravno, 11). Ljubljana, Svet za varstvo okolja RS, str. 99-102.

Humar, M., Kutnar, A., Piškur, M., 2013. Razvojne priložnosti slovenske lesnopredelovalne industrije. V: Ššštarič, N. (ur.). Kam plovemo? Premisleki o izhodu iz krize. Ljubljana, Založba Sanje, str. 89-100.

Jackson, T., 2009. Prosperity without growth? The transition to a sustainable economy. London, Sustainable Development Commission, 133 str. URL: http://www.sd-commission.org.uk/data/files/publications/prosperity_without_growth_report.pdf (Citirano 12. 9. 2014).

Kajfež Bogataj, L., 2012. Vroči novi svet. Ljubljana, Cankarjeva založba, 211 str.

Kajfež Bogataj, L., Zavšek Urbančič, M., Berložnik, B., Sušnik, A., Stražar, S., Cegnar, T., Gregorič, G., Roškar, J., Majer, D., Verbič, J., Kramberger, B., Jurc, M., Šestan, S., Erjavec, E., Erjavec, J., 2008. Strategija prilagajanja slovenskega kmetijstva in gozdarstva podnebnim spremembam. Ljubljana, Ministrstvo za kmetijstvo, gozdarstvo in prehrano, 15 str.

Karba, R., Sonnenschein, J., Miloševič, G., Rantaša, B., Slabe, A., Vovk, M., Žnidaršič, B., 2014. Zelena delovna mesta: stanje, potenciali, dobre prakse. Ljubljana, Umanotera, 110 str. URL: http://www.zelenadelovnamesta.si/upload/Zelena_delovna_mesta_analiza_mala.pdf (Citirano 15.10.2014).

Kazalci okolja Slovenije. 2014. Ljubljana, Agencija RS za okolje. URL: http://kazalci. arso.gov.si/?data=about (Citirano 7. 10. 2014).

Kazalniki zelene rasti. 2014. Ljubljana, Statistični urad Republike Slovenije, 50 str. URL: http://www.stat.si/doc/pub/Kazalniki_zelene_rasti.pdf (Citirano 2. 11. 2014).

Key figures on Europe. 2013. Luxembourg, European Environmental Agency, 184 str. DOI: $10.2785 / 35942$

Kirn, A., 2012. Družbenoekološki obrat ali propad. Ljubljana, Založba FDV, 239 str.

Kobold, M., Ulaga, F., 2010. Hidrološko stanje voda in podnebna spremenljivost. V: Cegnar, T. (ur.). Okolje se spreminja: podnebna spremenljivost Slovenije in njen vpliv na vodno okolje. Ljubljana, Agencija RS za okolje, str. 43-56.

Lampič, B., Mrak, I., 2008, Vrednote, vrednosti in razvojni potenciali območij varovanja. Dela, 29, str. 145-159. DOI: 10.4312/dela.29.11.145-159.

Lawler, J. J., Nelson, E., Conte, M., Shafer, S. L., Ennaanay, D., Mendoza, G., 2011. Modeling the impacts of climate change on ecosystem services. V: Kareiva, P., Tallis, H., Ricketts, T. H., Daily, G., Polasky, S. (ur.). Natural capital. Oxford, Oxford University Press, str. 323-338. DOI: 10.1093/acprof:oso/9780199588992.003.0018

Murn, A., 2013. Zagotoviti pogoje za trajnostni razvoj in nova delovna mesta. V: Šoštarič, N. (ur.). Kam plovemo? Premisleki o izhodu iz krize. Ljubljana, Založba Sanje, str. 49-67. 
Natek, K., 2005. Poplavna območja v Sloveniji. Geografski obzornik, 52, 1, str. 13-18.

Novak, P., Tomšič, M. G., 2004. Z učinkovitim ravnanjem z energijo do uspešnega razvoja. V: Lah, A. (ur.). Sonaravno uravnoteženi razvoj Slovenije (zbirka Usklajeno in sonaravno, 11). Ljubljana, Svet za varstvo okolja RS, str. 105-110.

Ogorelec, V., Karba, R., 2013. Zeleni preboj iz krize - pozitivna vizija za Slovenijo. V: Šoštarič, N. (ur.). Kam plovemo? Premisleki o izhodu iz krize. Ljubljana, Založba Sanje, str. 101-106.

Ogrin, D., 2003. Spreminjanje temperature zraka in padavin po letnih časih v Ljubljani in Trstu v obdobju 1851-2002. Dela, 20, str. 115-132. DOI: 10.4312/dela.20.11.115-131

Ogrin, D., 2009. Slabitev celinskih podnebnih značilnosti v zadnjih desetletjih. V: Kikec, T. (ur.). Pomurje: geografski pogledi na pokrajino ob Muri. Murska Sobota, Zveza geografov Slovenije, str. 66-78.

Ogrin, M., Vintar Mally, K., 2013. Primerjava poletne onesnaženosti zraka z dušikovim dioksidom v Ljubljani med letoma 2005 in 2013. Dela, 40, str. 55-72. DOI: 10.4312/ dela.40.4.55-72

Omladič, L., 2011. Onstran trajnostnega razvoja. Alternative 2011 (posebna številka Mladine). Ljubljana, str. 123-125. URL: http://www.mladina.si/media/objave/dokumenti/2012/2/3/alternative_november_2011.pdf(Citirano 25. 9. 2014).

Perpar, A., Udovč, A., 2010. Realni potencial za lokalno oskrbo s hrano v Sloveniji. Dela, 34, str. 187-199. DOI: 10.4312/dela.34.10.187-199

Piketty, T., 2014. Capital in the twenty-first century. Cambridge (Mass.), London, Belknap Press of Harward University Press, 685 str.

Plan B za Slovenijo 4.0 - Za zeleni razvojni preboj: prispevek za Strategijo razvoja Slovenije 2014-2020. 2012. Ljubljana, Umanotera, 42 str. URL: http://www.planbzaslovenijo.si/upload/SRS/plan-b-zeleni-razvojni-preboj.pdf (Citirano 14. 10. 2014).

Plut, D., 2012. Prehranska varnost sveta in Slovenije. Dela, 38, str. 5-23. DOI: 10.4312/ dela.38.1.5-23

Plut, D., 2013. Vodna, energetska ter prehranska samooskrba Slovenije in Gorenjske: možnost ali utopija? V: Rogelj, B., Potočnik Slavič, I., Mrak, I. (ur.). Gorenjska v obdobju glokalizacije. Ljubljana, Znanstvena založba Filozofske fakultete, str. 151-164. URL: http://geo.ff.uni-lj.si/sites/default/files/g3-net.pdf (Citirano 27. 9. 2014).

Plut, D., 2014. Ekosocializem ali barbarstvo: demokratični ekološki socializem in trajnostni sonaravni razvoj. Ljubljana, Društvo Gibanje za trajnostni razvoj Slovenije, 296 str.

Plut, D., Adamič, M., Kryštufek, B., Lampič, B., Medved, S., 2004. Vrednotenje vloge naravnih virov (okoljskega kapitala) Slovenije v Strategiji razvoja Slovenije z vidika konkurenčnosti in kakovosti življenja. Ljubljana, Oddelek za geografijo Filozofske fakultete, 116 str.

Pohleven, F., 2010. Življenje lesa. V: Obvladajmo podnebne spremembe - uporabimo les. Ljubljana, Slovenska gozdno-lesna tehnološka platforma, str. 6-13.

Poročilo o razvoju 2012. 2012. Ljubljana, Urad za makroekonomske analize in razvoj, 242 str. URL: http://www.umar.gov.si/fileadmin/user_upload/publikacije/pr/2012/ PoR_2012.pdf (Citirano 11. 10. 2014). 
Poročilo o razvoju 2013. 2013. Ljubljana, Urad za makroekonomske analize in razvoj, 232 str. URL: http://www.umar.gov.si/fileadmin/user_upload/publikacije/pr/2013/ POR_2013s.pdf (Citirano 9. 10. 2014).

Poročilo o stanju kmetijstva, živilstva, gozdarstva in ribištva v letu 2011. 2012. Ljubljana, Ministrstvo za kmetijstvo in okolje, Kmetijski inštitut Slovenije, 161 str. URL: http://www.mko.gov.si/fileadmin/mko.gov.si/pageuploads/podrocja/ZP_2011_ splosno_28.6.12.pdf (Citirano 6. 11.2014).

Poročilo Zavoda za gozdove o gozdovih leta 2012. 2013. Ljubljana, Zavod za gozdove Slovenije, 133 str. URL: http://www.zdravgozd.si/dat/letna_porocila/2012/opisno/ slo.pdf (Citirano 5. 11. 2014).

Potočnik Slavič, I., 2010. Endogeni razvojni potenciali slovenskega podeželja (Zbirka GeograFF, 7). Ljubljana, Znanstvena založba Filozofske fakultete, 131 str.

Rejec Brancelj, I., Dobnikar-Tehovnik, M., Uhan, J., 2011. Bistvene značilnosti nacionalnega načrta upravljanja voda 2009-2015 in izvajanje Vodne direktive. V: Volfand, J. (ur.). Upravljanje voda v Sloveniji. Celje, Fit media, str. 8-19.

Renewable internal freshwater resources per capita. 2012. New York, The World Bank. URL: http://data.worldbank.org/indicator/ER.H2O.INTR.PC (Citirano 6. 11. 2014).

Renner, M., Sweeney, S., Kubit, J., 2009. Employment in a low-carbon world. V: State of the world. New York, Worldwatch Institute, str. 115-118. URL: https://www.ilr. cornell.edu/globallaborinstitute/research/upload/SOW09_CC_jobs-1.pdf (Citirano 10. 10. 2014).

Resolucija o nacionalnem programu razvoja energetike. 2004. Uradni list RS, 57. URL: http://www.pisrs.si/Pis.web/npbDocPdf?idPredpisa=NACP45\&type=pdf (Citirano 25. 9. 2014).

Rifkin, J., 2010. The empathic civilisation: the race to global consciousness in a world in crisis. Cambridge, Polity Press, 688 str.

Sonnenschein, J., 2013. Zelena proračunska reforma za Slovenijo: odzivanje na krizo s trajnostno vizijo. Ljubljana, Umanotera, 60 str. URL: http://www.planbzaslovenijo.si/ upload/stories/zpr/umanotera\%20-\%20zelena\%20proracunska\%20reforma\%202013. pdf (Citirano 24. 9. 2014).

Stanič, G., 2013. Voz po klancu navzgor. Delo (9. 9. 2013). Ljubljana. URL: http://www. delo.si/mnenja/gostujoce-pero/voz-po-klancu-navzgor.html (Citirano 28. 9. 2014).

Stutz, F. P., Warf, B., 2005. World economy: resources, location, trade and development. Upper Saddle River (New Jersey), Prentice Hall, 543 str.

Suhadolc, M., Sušnik, A., Lobnik, F., Kajfež Bogataj, L., Gregorič, G., Bergant, K., 2010. Izzivi Slovenije na področju sušin degradacije tal: uresničevanje ciljev KonvencijeZN o boju proti degradaciji/dezertifikaciji tal (UNCCD). Ljubljana, Agencija RS za okolje, 75 str. URL: http://meteo.arso.gov.si/uploads/probase/www/agromet/product/ document/sl/IZZIVI_Slovenije_na_podrocju_sus_in_degradacije_tal.pdf (Citirano 3. 10. 2014).

The European environment - state and outlook 2010. 2010. Luxembourg, European Environment Agency. URL: http://www.eea.europa.eu/soer (Citirano 15. 9. 2014). 
Vendramin, M., 2011. Kaj, če bi se prebudili? Alternative 2011 (posebna številka Mladine). Ljubljana, str. 77-79. URL: http://www.mladina.si/media/objave/dokumenti/2012/2/3/alternative_november_2011.pdf (Citirano 5. 10. 2014).

Vintar Mally, K., 2009. (Ne)sonaravnost razvoja slovenskih regij. V: Nared, J., Perko, D. (ur.). Razvojni izzivi Slovenije. Ljubljana, Založba ZRC, str. 263-270.

Vogrinec, J., 2013. Trajnostni, vzdržen ali neskončen razvoj? V: Šoštarič, N. (ur.). Kam plovemo? Premisleki o izhodu iz krize. Ljubljana, Založba Sanje, str. 113-118.

Zakon o podnebnih spremembah (osnutek, 2. 6. 2010). 2010. Ljubljana, Služba vlade RS za podnebne spremembe, 46 str. URL: http://www.vlada.si/fileadmin/dokumenti/ si/projekti/2010/Zakon_o_podnebnih_spremembah_splet.pdf (Citirano 7. 10. 2014). Zelena knjiga za Nacionalni energetski program Slovenije. 2009. Ljubljana, Inštitut Jožef Stefan, 86 str. URL: http:/www.mg.gov.si/fileadmin/mg.gov.si/pageuploads/Energetika/Porocila/Zelena_knjiga_NEP_2009.pdf (Citirano 6. 10. 2014).

\section{GEOGRAPHICAL SCHEME OF SUSTAINABLE DEVELOPMENT AND SELF-SUPPLY IN SLOVENIA}

\section{Summary}

Contemporary, sustainable comprehension of development deals equally with economic, social and environmental objectives, assigns a more decisive role to food and energy self-supply, and also takes account of the needs of future generations. Planning the rise of material well-being on the basis of the current model of quantitative economic growth is environmentally and spatially unsustainable; it is urgent to implement a sustainably devised developmental paradigm, including a safe level of food and energy selfsupply on the national and regional levels.

In view of sustainable development, characteristic of Slovenia are stabilization of the population and population pressures on environment and space, minor towns, considerable settlement dispersion and small settlements, abundant water resources, well preserved nature as to European standards, and quality dwelling environment on the major part of its territory. Slovenia excels in exceptional landscape and biotic diversity, yet it manifests excessive use of natural resources, and diverse forms of environmental and spatial burdening occur, including spatially rounded-off areas of intense and multi-level landscape degradation. As to the use of natural resources and production of emissions per inhabitant, Slovenia exceeds the sustainably acceptable planetary level by two to four times, and its ecological footprint per inhabitant is almost twice as big as the biocapacity of Slovenia. Also because of the crisis conditions, high unemployment rate, the exhausted current developmental model and intergenerational moral and environmental obligations, Slovenia definitely needs a radically changed developmental paradigm, a complete social-environmental turnabout.

The multi-level crisis reveals the structural inefficiency of the current developmental model and technological lag of economy, therefore we believe that a sustainable economic 
and regional development and the rise in self-supply (both on national and regional levels) are the necessary and suitable economic, environmental and social responses. A long-term solution to the crisis is therefore not to continue the neoliberal developmental concept but to devise and implement a sustainable development concept, both for Slovenia as a whole and all its individual regions, which will pursue the welfare of the citizens of the present and future generations and, doing so, balance the economic, social and environmental development. During the industrial era Slovenia had only scarce local resources (lignite, some ores). But for the future era of sustainable developmental model, Slovenia has the essential strategic developmental-protective (environmental resources) and self-supply potentials:

- diverse and abundant internal and transit water resources;

- forest ecosystems and other renewable energy resources;

- the existing and potential (a few decades ago still cultivated) farming lands.

Underlined as an important environmental resource should also be the exceptional geographic and biotic diversity of Slovenia which figures as a component of healthy dwelling environment and a very important natural tourism potential.

The available quantity of internal waters per inhabitant is two times as high as the European average, and the technically exploitable potential of renewable energy resources exceeds the consumption of primary energy by one size class. According to the majority of assessments of theoretically and economically exploitable potential of renewable energy resources, the key long-term domestic resources, apart from hydro-power, prove to be solar and geothermal energy, and partly also wood biomass. The rich variety and capacity of regional renewable energy resources enable Slovenia as a whole and all Slovenian regions individually - if energy consumption is reasonable, i.e. reduced - to become permanently energy independent, i.e. energy self-supplying. Provided the consumption is sparing and stable, which means sustainable, the domestic environmental resources allow continuous and reliable self-supply with water, renewable energy resources, wood, favourable dwelling environment and the performing of the essential ecosystem functions.

Slovenia has sustainable environmental resources that can significantly increase its self-supply. An up-to-date sustainably devised strategy of development should also include a safe level of water, food and energy self-supply. Slovenia and its regions should certainly not become autarkic, self-sufficient communities; however, economy-related and cultural openness in the time of globalization should be balanced with regionalization (decentralization) mechanisms of enhancing the multi-level national and regional identity, including greater water, energy and food self-supply.

Local environmental resources and the very favourable geographical position and moderate population density of Slovenia enable it to pursue the path of sustainable development innovatively, more energetically and with greater self-confidence. Environmental technologies and green entrepreneurship, environmentally responsible use of domestic environmental resources, sustainable agriculture, tourism, transportation (rail and public; cycling) and building industry (energy retrofit of houses, building passive houses, local building materials), and ecology-oriented other activities should become, in view of export-oriented Slovenian industry (potential for about 20,000 new jobs), the core of Slovenian innovative, 
sustainable developmental-environmental breakthrough. It opens a minimum of 60,000 new regionally dispersed green jobs (halving the unemployment rate) through increased wood processing, the minimum of $20 \%$ increase in food safety, regional use of renewable energy resources, sustainable tourism and energy retrofit of buildings. It is difficult to predict what percentage of the total Slovenian potential of green jobs (about 250,000; in 2013 there were 30,000) will be realized in the coming decades. To effectuate a sustainable economic breakthrough of Slovenia, big efforts will be required of all the involved agents (private and public enterprises, farmers, a stimulating legal and fiscal framework, development of sustainably devised market, adequate knowledge and skills, better environmental awareness, etc.) and a strong political support on the European, national and local levels.

We believe that among the sustainable self-supply fields on the national level, priority should be given to reaching again a safe degree in food self-supply; production of local high-quality and healthy food is very likely the most demanding strategic task of sustainable development on the state level. Particularly due to the moderate degree of food self-supply in Slovenia (slightly above 50\%), it is improper to use agricultural lands for the production of biofuels; and in the future, more water (small reservoirs) will have to be intended for irrigation. A higher degree of self-supply and reduced import of raw materials, food and energy mean that ecological and carbon footprints are significantly reduced and thus a greater share is contributed to the planetary environmental and social responsibility and sustainable development breakthrough.

It is necessary to devise and implement national sustainable developmental projects for:

- sustainable living supported by setting up pilot eco-villages and urban eco-communities;

- increase in food and energy self-supply of Slovenia, its regions and municipalities (pilot self-supplying municipalities);

- sustainable economy and use of local resources in various types of protected areas of Slovenia;

- sustainable development of tourism in rural areas and in towns;

- adaptation to climate changes of the entire economy, settling, the way of living;

- ecoremediations as the basic sustainable methods of reducing and preventing unsustainable modes of living and economy on the state and particularly on the regional and local levels.

As concerns the strategy, the globalized Slovenian economy will have to cope by 2020 with the following issues in particular in the environmental-developmental field:

- radical energy-environmental reorientation towards a low-entropy and low-carbon society, based both on adaptation to climate changes and on the demanding participation in the implementation of the EU 2020 climate and energy package: $20 \%$ reduction of greenhouse gasses emissions, $20 \%$ increase in energy efficiency and increase in the use of renewable resources to $20 \%$ of the final energy consumption;

- accelerated identification and inclusion of all environmental-climatic external costs in the prices of products and services, which will, besides other benefits, essentially change the relations between the prices of energy resources and the ecosystem significance of bio-productive lands; 
- larger contribution of Slovenian economy to the search for sustainably optimal responses to contemporary challenges to national safety in a broader sense, the significant components of which are water, climate and food safety (tendency towards selfsupply, maintaining strategically already critical relation between farming, forest and built-up areas), increase in energy safety, stabilization and then reduction in energy consumption, greater but ecologically well-considered use of local renewable energy resources, preservation of ecosystem services, landscape and biotic diversity, and also environmentally balanced, coordinated regional development of the entire settled territory of Slovenia.

If Slovenia does decide in favour of a sustainable vision of development, this will open a possibility of making responsible and effective use of the abundant and regionally varied sustainable natural potentials and the knowledge of the young generation, in order to improve low-carbon and sustainable economy, increase the employment and self-supply, achieve a better balanced sustainable regional development, adapt to climate changes and reduce environmental pressures. Rich and manifold geographical developmental-protective potentials of Slovenia and all its regions are its sustainable basis and great opportunity. 